NBER WORKING PAPER SERIES

\title{
THE IMPACT OF FINANCIAL ASSISTANCE PROGRAMS ON HEALTH CARE UTILIZATION
}

\author{
Alyce S. Adams \\ Raymond Kluender \\ Neale Mahoney \\ Jinglin Wang \\ Francis Wong \\ Wesley Yin \\ Working Paper 29227 \\ http://www.nber.org/papers/w29227 \\ NATIONAL BUREAU OF ECONOMIC RESEARCH \\ 1050 Massachusetts Avenue \\ Cambridge, MA 02138 \\ September 2021
}

We thank Andrea Altschuler, Somalee Banerjee, and Lin Ma for substantial assistance during the course of this study. This work was supported by the Becker-Friedman Institute at the University of Chicago and the National Institute on Aging, Grant Number T32-AG000186 as well as the Targeted Analysis Plan sponsored by the Kaiser Permanente Delivery Science and Applied Research Program. The views expressed herein are those of the authors and do not necessarily reflect the views of the National Bureau of Economic Research.

NBER working papers are circulated for discussion and comment purposes. They have not been peer-reviewed or been subject to the review by the NBER Board of Directors that accompanies official NBER publications.

(C) 2021 by Alyce S. Adams, Raymond Kluender, Neale Mahoney, Jinglin Wang, Francis Wong, and Wesley Yin. All rights reserved. Short sections of text, not to exceed two paragraphs, may be quoted without explicit permission provided that full credit, including $(\odot)$ notice, is given to the source. 
The Impact of Financial Assistance Programs on Health Care Utilization

Alyce S. Adams, Raymond Kluender, Neale Mahoney, Jinglin Wang, Francis Wong, and Wesley Yin

NBER Working Paper No. 29227

September 2021

JEL No. I1,I18

\section{ABSTRACT}

Most hospitals and managed care organizations have financial assistance programs that aim to reduce financial burdens and improve health care access for low-income patients. We use administrative data from Kaiser Permanente to study the effects of financial assistance on health care utilization. Using a regression discontinuity design based on an income threshold for program eligibility, we find that financial assistance significantly increases health care utilization initially, though effects dissipate three quarters after program receipt. Financial assistance also increases the detection of and medication refills for treatment-sensitive conditions, suggesting financial assistance may increase receipt of high-value care.

Alyce S. Adams

Department of Epidemiology

and Population Health, and of Health Policy

Stanford University

150 Governor's Lane

HRP Redwood Building, Rm \#109

Stanford, CA 94305-5405

and Kaiser Permanente

Division of Research (Adjunct Investigator)

asadams@stanford.edu

Raymond Kluender

Harvard Business School

Rock Center 217

Soldiers Field Rd

Boston, MA 02163

rkluender@hbs.edu

Neale Mahoney

Department of Economics

Stanford University

579 Jane Stanford Way

Stanford, CA 94305

and NBER

nmahoney@stanford.edu
Jinglin Wang

New York University

jinglin.wang23@gmail.com

Francis Wong

National Bureau of Economic Research

Cambridge, MA 02138

fwong@nber.org

Wesley Yin

University of California, Los Angeles

3250 Public Affairs Building

Los Angeles, CA 90095

and NBER

wyin@ucla.edu 


\section{Introduction}

The provision of financial assistance to indigent patients is a longstanding component of the US health care system. Throughout much of the $18^{\text {th }}$ and $19^{\text {th }}$ centuries, hospitals were primarily charitable institutions, providing free care to people who could not afford home-based care. During the late $19^{\text {th }}$ and $20^{\text {th }}$ centuries, advances in medical knowledge made hospitals attractive to a broader set of patients, and financial assistance evolved to fill the gaps left by a burgeoning health insurance system (Starr, 2008). In the 1960s, federal law formally encouraged financial assistance as a way for non-profit hospitals to meet requirements for their tax-exempt status. In recent decades, federal and state legislation have increased requirements for the provision of financial assistance, both by non-profit and for-profit hospitals.

Today, most US hospitals have financial assistance programs that seek to reduce financial burdens and improve health care access for low-income patients by providing a combination of debt forgiveness and reduced out-of-pocket costs (see Table 1, discussed below). ${ }^{1}$ These programs target both uninsured and insured patients and are common across hospital ownership types. In 2018, hospitals provided a total of $\$ 26$ billion in charity care, of which $\$ 20$ billion was provided to uninsured patients and $\$ 6$ billion provided to insured patients (Roth et al., 2021). Charity care accounted for $1.5 \%$ of total expenses for the median non-profit hospital, $1.4 \%$ of total expenses at the median for-profit hospital, and $0.9 \%$ of total expenses at the median government hospital (Bai et al., 2021).

Charity care provided through financial assistance programs has been at the center of a policy debate over whether non-profit hospitals provide sufficient "community benefits" to justify their tax-exempt status. ${ }^{2}$ The prior literature has largely focused on the dollar value of financial assistance, drawing on hospital-level data on charity care and bad debt collectively referred to as uncompensated care - from the American Hospital Association

\footnotetext{
${ }^{1}$ Examples of stated aims include: "improving health care access for people with limited incomes and resources" (Kaiser Permanente); "provide medically necessary healthcare to everyone, regardless of the ability to pay" (Community Healthcare System); and "providing quality health care services to all our patients regardless of their financial situation" (Mercy).

${ }^{2}$ See, for example, Senator Grassley's investigations discussed in https: / / www. nytimes.com/2009/ 06/01/us/politics/01health.html and https://www.modernhealthcare.com/government/ grassley-back-it-ramping-up-scrutiny-tax-exempt-hospitals.
} 
Annual Survey and the publicly available Hospital Cost Reports. Researchers have used these datasets to document trends in uncompensated care and to examine how insurance coverage has impacted uncompensated care (e.g., Garthwaite et al., 2018; Cunningham and Tu, 1997; Dranove et al., 2016; Mann et al., 1997; Camilleri, 2018).

While prior studies measure the implications of uncompensated care on hospital finances, little is known about whether financial assistance programs improve health care access (i.e., increase health care utilization among those who may be deterred by costs). In principle, financial assistance could impact health care utilization through the price effects of reduced out-of-pocket costs and the wealth effect of relief from previously accrued medical bills. However, identifying the causal impact of financial assistance programs is challenging because selection into these programs is typically endogenous to past or expected future utilization. And because patients may seek care from multiple health care providers, estimating the full impact of a hospital's financial assistance program can be hamstrung by incomplete data on health care utilization.

This study estimates the impact of Kaiser Permanente Northern California's financial assistance program on health care utilization. Kaiser Permanente provides an ideal setting for studying the impacts of financial assistance programs for three reasons. First, Kaiser Permanente's program is representative of financial assistance programs at other large health care systems, offering a combination of debt write-downs for previously incurred unpaid medical bills and the elimination of cost sharing for health care over subsequent months. Second, eligibility is determined by a strict income cutoff rule at $350 \%$ of the Federal Poverty Level (FPL), which provides identifying variation in the form of a regression discontinuity (RD) design. Third, Kaiser Permanente operates a large, integrated closed-network health system, which means that patients can receive all types of care at Kaiser Permanente facilities. While our data allow us to observe some instances of care received at non-Kaiser facilities, the integrated insurer-provider system means that virtually all care occurs at Kaiser facilities, allowing us to observe complete information on health care utilization, drug prescriptions, and diagnostic tests of program applicants.

We use an RD based on an eligibility cutoff at 350\% of FPL to estimate the causal effects of the financial assistance program at this discontinuity. We observe administrative 
data on income, family size, and other demographics for over 25,000 program applicants. Using these data, we estimate a sharp 78.8\% increase in approval for applicants below the threshold. Virtually all applicants below the threshold are approved while a small percentage of applicants above the threshold qualify through a separate expense-based criterion. In support of the research design, we show that patient demographics and prior health care utilization trend smoothly through the discontinuity. As a placebo check, we find no effects at the discontinuity in any of the seven quarters before application. Finally, we do not detect bunching of income below the discontinuity, which suggests limited scope for income manipulation. Collectively, these results support the identification assumption that applicants immediately above and below the income eligibility threshold are similar, and that the results are not driven by confounding selection into program eligibility.

We find that financial assistance increases health care utilization in the first quarter following application. Our preferred instrumental variable (IV) estimates, which scale up our estimates to account for the $78.8 \%$ increase in approval at the threshold, indicate that approval leads to a 3.6 percentage point (pp) increase in the likelihood of an inpatient encounter (relative to a mean of $6.2 \%$ ), a $13.4 \mathrm{pp}$ increase in the likelihood of an ambulatory encounter (relative to a mean of $67.0 \%$ ), and a $6.7 \mathrm{pp}$ increase in the likelihood of an emergency department encounter (relative to a mean of $12.7 \%$ ). We estimate a fairly large increase in prescription drug utilization (an increase of 32.0 in prescription drug days supplied relative to a mean of 136.0 days) and marginally significant increases in utilization of drugs to treat cholesterol, diabetes, and depression. The effects we observe decline in the second quarter and largely disappear by the third quarter after the date of the application decision.

The first quarter impacts on utilization are large in magnitude. As a benchmark, they are proportionally similar to the effects of Medicaid on health care utilization reported in the Oregon Health Insurance Experiment (Finkelstein et al., 2012; Taubman et al., 2014) over the first year-and-a-half of the program. In other words, the initial impacts of the financial assistance program on health care utilization in our insured study population are similar in magnitude to the impacts of providing Medicaid to the uninsured in Oregon. However, unlike the effects of Medicaid which persist for at least the year-and-a-half 
study period, the effects of the financial assistance program tail off by the third quarter. The comparison highlights differences between hospital financial assistance programs and Medicaid coverage, which we discuss in Section V.

In addition to the effects on utilization, we find that financial assistance increases testing for and detection of health conditions. Specifically, our IV estimates indicate a $4.0 \mathrm{pp}$ increase in the probability of an abnormal test result (relative to a mean of $10.0 \%$ ). This effect is driven by an extensive margin increase in testing; conditional on having a test, the probability of an abnormal result is unchanged. We also find increased drug utilization for treatment-sensitive conditions. Taken together, the increased detection of abnormal health conditions - a precondition for appropriate treatment - along with increased drug utilization, suggest that at least some of the increase in health care utilization caused by the financial assistance program is high value. This finding is consistent with emerging evidence of the detrimental effects of consumer cost-sharing on the utilization of high-value care (Chandra et al., 2010; Brot-Goldberg et al., 2017).

Our research builds on two correlational studies that have examined the effects of financial assistance programs on health care utilization. Based on a survey of 308 (insured) patients, Conner et al. (2013) find that enrollment in a financial assistance program is associated with reduced health care utilization and no change in self-reported physical or mental health. Chaiyachati et al. (2020) examine the association between non-profit hospital community benefit spending and hospital readmission rates for Medicare patients but finds no statistically significant relationship. In contrast to these studies, our quasi-experimental evidence indicates that financial assistance causes a substantial increase in health care utilization and detection of health conditions, albeit over a limited time horizon.

Our study also complements the literature on hospital-level uncompensated care, mentioned above. This includes descriptive research on patterns in uncompensated care over time and across different types of hospitals (Cunningham and Tu, 1997; Mann et al., 1997) as well as research evaluating whether the amount of charity care provided by non-profit hospitals is commensurate with the favorable tax treatment they receive (Young et al., 2013; Singh et al., 2015; Herring et al., 2018). ${ }^{3}$ The literature also includes research on the role

\footnotetext{
${ }^{3} \mathrm{~A}$ number of papers have examined financial assistance policies for cancer treatment and drug costs
} 
that hospitals play as insurers of last resort by providing vulnerable patients medical care that is ultimately uncompensated (Garthwaite et al., 2018; Dranove et al., 2016; Camilleri, 2018). In particular, our study sample is comprised primarily of insured patients who may nevertheless face significant out-of-pocket costs. The estimated utilization effects for this population contribute to our understanding of the role that hospitals serve as safety net insurers among insured patients who increasingly face high out-of-pocket costs. ${ }^{4}$

\section{Background}

\section{A Hospital Financial Assistance Programs}

Financial assistance policies have a long history in the US. In 1954, the federal government added section 501(c)(3) to the Internal Revenue Code, which provided organizations dedicated to religious, charitable, scientific, or educational purposes with an exemption from paying federal income taxes. To qualify for tax-exempt status, a hospital had to provide "to the extent of its financial ability, free or reduced-cost care to patients unable to pay for it" (James, 2016). Since 1969, hospitals have been able to use financial assistance to fulfill their "community benefits" requirement for tax-exempt status (Somerville, 2012). While the IRS has given hospitals flexibility in determining which expenditures count towards community benefits (James, 2016), recent evidence indicates that charity care and other services account for about $85 \%$ of these expenditures (Young et al., 2013). Starting in 2015, the Affordable Care Act (ACA) imposed additional requirements on non-profit hospitals, including establishing a written financial assistance policy (IRS, n.d.; James, 2016). Financial assistance policies are also influenced by state-level regulations. As of 2019, ten states require both non-profit and for-profit hospitals to provide free or discounted care to eligible patients, and other financial assistance requirements exist in additional states (Stark, 2020).

We gathered information on the financial assistance programs offered by the 40 largest

(Felder et al., 2011; Semin et al., 2020; Zullig et al., 2017). These correlative studies typically find that financial assistance offers imperfect protection against financial hardship (Paul et al., 2016) and are subject to substantial frictions that deter take-up (Spencer et al., 2018).

${ }^{4}$ See, for example, https://www.healthsystemtracker.org/brief/tracking-the-risein-premium-contributions-and-cost-sharing-for-families-with-large-employercoverage/ 
health care systems from their websites. Table 1 displays income-based eligibility criteria and benefits for the 4 largest for-profit and 4 largest non-profit systems with available information. We also provide information for Kaiser Permanente Northern California, which is the focus of our study. Appendix Section A describes the methodology used to gather information and Appendix Table A1 provides eligibility and benefits information for all 40 health systems.

Among health systems with available information, eligibility cutoffs range from $200 \%$ to $400 \%$ of FPL. Applicants may also qualify if they have substantial health care expenses relative to their means. Qualifying patients typically receive some combination of forgiveness of previously incurred medical bills and reduced out-of-pocket costs for future care, often with more generous benefits for lower-income patients. While for-profits do not face the same federal regulatory requirements as non-profits, the largest for-profit health systems offer financial assistance programs that are comparable in their eligibility criteria and benefits to non-profit health systems.

\section{B Financial Assistance at Kaiser Permanente}

Kaiser Permanente is a large, closed-network health care system that operates 39 hospitals and over 700 medical offices across eight states, serving 12.5 million patients. ${ }^{5}$ As part of the ACA requirement for non-profit health care providers, Kaiser Permanente maintains a set of financial assistance policies similar in eligibility and generosity to those offered by other large hospital systems. For this study, we use data from Kaiser Permanente Northern California, a division within Kaiser Permanente serving 4.5 million people in the San Francisco Bay Area, Greater Sacramento, and the Central Valley.

Kaiser Permanente Northern California patients qualify for financial assistance if they have family income at or below $350 \%$ of FPL. Patients can also qualify with incomes above the $350 \%$ FPL threshold if they have eligible out-of-pocket medical and pharmacy expenses exceeding $10 \%$ of household income over a 12-month period (regardless of FPL). The majority of patients $(71 \%)$ who enroll in financial assistance qualify based on their incomes.

Patients can learn about the financial assistance program through several channels.

\footnotetext{
${ }^{5}$ Source: https: //about.kaiserpermanente.org/who-we-are/fast-facts
} 
Information on the program is included on medical bills sent to patients, as well as online. Case workers and caregivers can also provide patients with information in person at Kaiser facilities and assist patients in applying to the program.

Kaiser Permanente Northern California's financial assistance eliminates both existing debts and cost sharing for future care. Patients receive a full discount on unpaid bills previously incurred at Kaiser. Patients in a Medicare Advantage plan face no copays for 6 months after receipt, and patients in a non-Medicare Advantage plan (e.g., employersponsored or Marketplace) face no copays for 12 months. The program applies to virtually all health care delivered by Kaiser, including care provided at Kaiser hospitals and clinics, as well as drugs provided at Kaiser pharmacies.

\section{Data}

We obtained deidentified administrative data on all applicants to the Kaiser Permanente Northern California financial assistance program between January 2016 and December 2017. For each applicant, we observe income, family size, demographics, whether the patient applied via the income or expense-based criteria, and whether the application was approved or denied.

Kaiser Permanente offers an ideal setting to study the impacts of financial assistance on health care utilization. Because it is an integrated closed-network system, we observe detailed electronic medical records information for $96.3 \%$ of health care expenses incurred by program applicants. ${ }^{6}$ This allows us to observe ambulatory visits, emergency department visits, and inpatient hospital stays, as well as information on prescription drug use, laboratory tests and results, and total health care costs. We observe utilization, prescription drugs, and laboratory test results from a period 24 months before to 24 months after the month of the program application decision. We observe costs for the 12-month period before the application decision.

We focus our analysis on the discontinuity created by the income eligibility cutoff at $350 \%$ FPL. While the expense eligibility criterion also creates a discontinuity, data on out-

\footnotetext{
${ }^{6}$ On average, only $3.7 \%$ of total expenses for individuals in our baseline sample were incurred for medical services outside of Kaiser in the 12-month period before the application decision.
} 
of-pocket bills at the time of eligibility were not available so we cannot use this threshold as a research design. A total of 25,574 patients with available information on income and family size applied via the income-based criteria. We drop patients with incomes below $150 \%$ FPL or above $550 \%$, yielding a symmetric window around the $350 \%$ FPL cutoff. Of the 18,695 applicants in the remaining sample, 13 applied more than once. We exclude these individuals because the subsequent applications may be endogenous to information concerning their likelihood of subsequent approval. The resulting baseline sample has 18,672 applicants.

For each applicant in our baseline sample, we construct a monthly panel of outcomes on health care utilization for the period from 24 months before to 24 months after the month of application decision (total of 49 months). For most of the analysis, we aggregate the data to the quarterly frequency to reduce the noise inherent in higher-frequency measures. We define quarter 0 as months $0,-1$, and -2 , where month 0 is the month of the application decision; quarter 1 contains months 1, 2 and 3 after application; and so on.

Our primary measures of health care utilization are indicators for whether a patient had at least one (i) ambulatory visit, (ii) inpatient visit, (iii) emergency department visit, (iv) visit of any kind (i.e., ambulatory, inpatient, or emergency department), and (v) the number of prescription drug days supplied, in the quarter. Our laboratory test data cover tests for cholesterol (HDL and total), triglycerides, and blood sugar (A1C). Cholesterol and triglycerides tests are used to assess risk and guide treatment of heart disease; A1C tests are used to manage treatment of diabetes. We construct an indicator for whether a patient had at least one laboratory test and whether the test returned at least one abnormal result. ${ }^{7}$

Table 2 provides summary statistics on our baseline sample in quarter -1 (covering months $-3,-4$, and -5 , relative to the month of application decision). Column 1 shows means for the baseline sample with incomes between $150 \%$ and $550 \%$ of FPL. On average, applicants have a family income of $\$ 40,000$, have a family size of slightly more than 2 , and are 58 years old. The average Elixhauser Comorbidity Index (count of chronic conditions)

\footnotetext{
${ }^{7}$ We follow clinical guidelines and define an abnormal test as less than $40 \mathrm{mg}$ per deciliter for HDL cholesterol level, $240 \mathrm{mg}$ per deciliter or higher for total cholesterol, $150 \mathrm{mg}$ per deciliter or higher for triglycerides, and $6.5 \%$ or higher for A1C for adults (Ma and Shieh, 2006; International Expert Committee, 2009). We use the corresponding thresholds from the same source for the small number of children in our sample.
} 
is 3.5 over the 12 months before application, higher than the average of 2.2 in the US population in 2013 (Akinyemiju and Moore, 2016). The average BMI among the applicants is 29.0, which is similar to the US population mean for both men (29.1) and women (29.6) over 20 (Fryar et al., 2018). Most (88\%) of applicants are enrolled in a Kaiser plan at the time of application, of which $52 \%$ are covered by a Medicare Advantage plan, and $48 \%$ are enrolled in a commercial plan (e.g., employer-sponsored or Marketplace). As expected given the circumstances, applicants had high health care costs in the months before application. In quarter -1 , average costs were slightly more than $\$ 6,000$, substantially higher than the \$2,686 average quarterly expenditure for Americans in 2017 (National Center for Health Statistics, 2021). Applicants' healthcare utilization are also correspondingly higher than the US population average.

Columns 2 and 3 of Table 2 report means for applicants with incomes between 250$350 \%$ and $350-450 \%$ of the FPL threshold, respectively. The small differences indicate that applicants on either side of the eligibility threshold are similar along key characteristics and pre-intervention outcomes. We conduct formal tests of the validity of the RD design, described below.

\section{Empirical Strategy}

We use an RD design that exploits the program eligibility threshold at 350\% of FPL to estimate the causal effect of the financial assistance program on health care utilization. Let $i$ index applicants and $t$ index quarters relative to application. For each quarter $t \in[-7,8]$, we estimate separate regressions of the form:

$$
y_{i t}=\beta_{0 t}+\beta_{1 t} F P L_{i}+\beta_{2 t} F P L_{i}^{2}+\delta_{t} \mathbb{1}\left(F P L_{i} \leq 350 \%\right)+\epsilon_{i t}
$$

where $y_{i t}$ is the outcome variable, and $F P L_{i}$ is the applicant's income as a percentage of FPL, which serves as the running variable. The coefficient of interest, $\delta_{t}$, captures the effect of having an income below the eligibility threshold on the outcome in quarter $t$.

In our baseline specification, we include a global second-order polynomial in income to capture the relationship between income and the outcome. A global polynomial is ap- 
propriate if the relationship between $y_{i t}$ and income would not exhibit a structural break at $350 \%$ in the absence of the financial assistance program, and allows us to accommodate the relatively small mass of observations to the right of the threshold. We show in sensitivity analysis that our results are similar (although noisier for some outcomes) when we allow for separate polynomials above and below the threshold.

Our identifying assumption is that in the absence of the discontinuity in program approval, outcomes would trend smoothly through the discontinuity. Below, we present three pieces of evidence in support of this assumption. First, we show that applicant characteristics, such as demographics and chronic health conditions, trend smoothly through the discontinuity. Second, as a placebo test, we show there are no effects on outcomes before application. Finally, we test for bunching of applicants below the eligibility threshold.

The validity of the research design is also supported by the institutional environment. Patients must document their income (e.g., by submitting a pay stub) which reduces the scope for manipulation of the running variable. Applications are typically submitted following a health event, limiting income manipulation through the retiming of applications.

As we show below, while virtually all applicants with incomes below the threshold qualify for the financial assistance program, a small share of applicants with incomes above the threshold qualify via the expense-based criteria. To account for these approvals, we estimate instrumental variable (fuzzy RD) specifications. Letting $F A P_{i}$ be an indicator for approval, the first stage takes the form:

$$
F A P_{i}=\alpha_{o t}^{I V}+\alpha_{1 t}^{I V} F P L_{i}+\alpha_{2 t}^{I V} F P L_{i}^{2}+\gamma_{t}^{I V} \mathbb{1}\left(F P L_{i} \leq 350 \%\right)+v_{i t}
$$

and the second stage takes the form:

$$
y_{i t}=\beta_{0 t}^{I V}+\beta_{1 t}^{I V} F P L_{i}+\beta_{2 t}^{I V} F P L_{i}^{2}+\delta_{t}^{I V} F A P_{i}+\epsilon_{i t}^{I V}
$$

Since we have a single instrument, the IV coefficient of interest $\delta_{t}^{I V}$ is numerically equivalent to the RD estimate $\delta_{t}$ divided by the first stage effect $\gamma_{t}^{I V}$. 


\section{Results}

\section{A Balance and First Stage}

To examine selection into the program, we first test for discontinuities in pre-application patient characteristics and outcomes around the eligibility cutoff. Columns 4 and 5 of Table 2 report the coefficient and associated $p$-value on the indicator for having income below the $350 \%$ FPL threshold from our baseline RD specification (equation 1). The top panel shows effects for patient demographics and pre-application health conditions (Elixhauser comorbidity score, BMI, smoker). The middle panel shows effects on measures of insurance coverage (insured and Medicare Advantage) and quarterly costs, measured in the quarter before application.

Second, we implement placebo tests for differences in the outcomes before application. The bottom panel of Table 2 shows effects of our utilization outcomes, again measured in the quarter before application. The estimated effects are quantitatively small and statistically insignificant for every variable, supporting the assumption that outcomes would have evolved smoothly through the threshold in the absence of the financial assistance program. Appendix Figure A1 displays the RD plots for the quarter -1 placebo tests.

Third, we examine bunching of applications around the threshold value, which could indicate selection into the program on unobservable characteristics. Figure 1, Panel A presents a histogram of applicant income as a percentage of FPL for the unrestricted data and Panel B presents a histogram for our baseline sample of applicants with incomes between $150 \%$ to $550 \%$ FPL. Neither histogram shows visual evidence of excess mass to the left of the threshold. Appendix Table A2 presents results from the manipulation test developed by Cattaneo et al. (2020). The Cattaneo et al. (2020) test (henceforth, CJM) yields a $p$-value of 0.202 , indicating the absence of manipulation. We view the CJM test as conservative since the test over-rejects in a validation exercise. When applied to our data for placebo thresholds at $1 \%$ increments between $200 \%$ and $500 \%$ FPL, the test results in $p$ values of less than 0.05 for $16.6 \%$ of thresholds. See Appendix Section B for more details. ${ }^{8}$

\footnotetext{
${ }^{8}$ The problem of over-rejection appears to be even more severe for the commonly used McCrary (2008) test. In Appendix Section B, we show that the McCrary test rejects $40.5 \%$ of placebo thresholds between $200 \%$ and $500 \%$ FPL, suggesting that this test is not well-suited to detecting manipulation of the running variable in our
} 
We estimate a large first-stage effect of the cutoff on application approval. Figure 1, Panel C plots approval rates by FPL, along with fitted values from the first stage (equation 2). Applicants below the cutoff have a $78.8 \mathrm{pp}$ (standard error $1.7 \mathrm{pp}$ ) higher likelihood of being approved for the program. Virtually all applicants with incomes below the cutoff are approved, while about one-fifth of applicants above the cutoff qualify via the expensebased criteria.

\section{B Utilization Impacts}

We next turn to estimating the effects of the financial assistance program on health care utilization. Figure 2 presents RD plots of the impact of financial assistance in the first quarter following application decision. For each outcome, dots show the mean of the outcome variable for 85 equal-frequency bins of income. ${ }^{9}$ The solid lines show predicted values from the RD specification (equation 1) and dashed lines show the 95\% confidence intervals. For each outcome, we also report the RD and IV estimates, their standard errors, and the mean of the outcome for applicants with an income of $350-450 \%$ of FPL (i.e., the "control group" mean).

The IV estimates indicate substantial increases in utilization in the quarter after receiving financial assistance. Financial assistance increases the likelihood of any ambulatory encounter by $13.4 \mathrm{pp}$ (relative to a mean of $67.0 \%$ for those with income between $350-450 \%$ FPL), any inpatient encounter by $3.6 \mathrm{pp}$ (relative to a mean of $6.2 \%$ ), and any emergency department (ED) encounter by 6.7 pp (relative to a mean of $12.7 \%$ ). The likelihood of any encounter increases by $13.0 \mathrm{pp}$ (relative to a mean of $68.4 \%$ ) and the number of prescription drug days supplied increases by 32.0 (relative to a mean of 136.0). All of these estimates are statistically distinguishable from 0 at the $5 \%$ level.

We find that financial assistance has a large proportional effect on the likelihood of undertaking a laboratory test and on the detection of an abnormal test outcome in the quarter after program decision. Specifically, the likelihood of any test increases by 7.1 pp (relative to a mean of $19.4 \%$ ) and, unconditional on having a test, the likelihood of an setting.

${ }^{9}$ The number of bins was chosen to achieve bins with approximately equal observation counts on both sides of the discontinuity. Panel G has 31 bins due to its smaller sample size. 
abnormal test increases $4.0 \mathrm{pp}$ (relative to a mean of $10.0 \%$ ). The increase in abnormal test results is driven by the extensive margin increase in testing, given that the conditional likelihood of an abnormal test result is unchanged (point estimate of $1.0 \mathrm{pp}$ and standard error of $6.7 \mathrm{pp}$ relative to a mean of $51.5 \%$ ). Hence, marginal testing conducted in response to financial assistance leads to valuable diagnosis of abnormal health and is of similar diagnostic value to inframarginal testing.

In Appendix Table A3, we further examine effects on abnormal test results and prescription drug utilization separately by chronic condition that benefit from diagnosis and management. Financial assistance almost doubles the likelihood of an abnormal cholesterol test (2.6 pp increase relative to a mean of $2.7 \%$; $p$-value of 0.007 ) and raises utilization of cholesterol lowering drugs by a marginally significant 19\% (4.9 percentage point increase relative to a mean of $26.2 \%$; $p$-value of 0.08$).{ }^{10}$ The effect on diabetes diagnoses is imprecise, however we estimate a marginally significant $26 \%$ increase in prescriptions for diabetes (3.7 pp increase relative to a mean of $14.1 \%$; $p$-value of 0.087$)$. Financial assistance increases utilization for drugs to treat depression by about one-third (5.5 percentage points relative to a mean of $14.9 \%$; $p$-value of 0.16 ) and has an imprecise effect on prescriptions for blood pressure.

Taken together, the increased detection of abnormal health conditions - which are a precondition for appropriate treatment - along with the increased drug utilization for treatment-sensitive conditions suggest that financial assistance increases the use of highvalue care for at least some patients.

\section{Dynamics}

Figure 3 examines the dynamic effects of financial assistance on utilization by plotting RD estimates, and the corresponding 95\% confidence intervals, for quarters $t \in[-7,8] .{ }^{11}$ The plots show no effect in quarters -7 to -1 , supporting the validity of the research design. For some outcomes, there is a small effect in quarter 0 , which is natural since program approval occurs in the last month of this quarter. Impacts of financial assistance are largest

\footnotetext{
${ }^{10}$ We cannot separate whether the increase in drug utilization is directly caused by the financial assistance or by the diagnostic testing.

${ }^{11}$ Numerical values of the regression discontinuity and the IV estimates for each outcome in each quarter are reported in Appendix Tables A4 and A5.
} 
in quarter 1, half as large and not statistically significant for any of our primary outcomes in quarter 2, and small and generally not statistically significant in quarters 3 to 8 . Thus, while the impacts in the months immediately following program receipt are substantial, cumulative effects over longer time horizons are smaller.

\section{Sensitivity Analysis}

We conduct several sets of robustness analyses to address standard concerns surrounding RD designs, which complement the tests for balance and manipulation presented in Section V.A and the tests for impacts before the program presented in Section V.B.

Our baseline model controls for a global second-order polynomial in income rather than separate polynomials above and below the discontinuity. This specification assumes that there is not a structural break in the underlying relationship between health care utilization and income that could not be captured by this global polynomial. To probe the sensitivity to this assumption, Panel A of Appendix Table A6 shows estimates that control for separate second-order polynomials above and below the cutoff, and Panel B controls for separate local linear regressions using the approach proposed by Calonico et al. (2014). The estimates are similar up to some additional noise due to the relatively lower number of observations above the income the cutoff.

To provide further assurance that our results are not being driven by observations close to the income cutoff, we re-estimate our main specification using a "donut" RD design where we exclude observations with incomes between $340 \%$ and $360 \%$ of FPL (see Appendix Table A6, Panel C). The estimated impacts are very similar to our baseline specification.

\section{Discussion}

The goal of financial assistance programs is to provide financial relief to patients for previously incurred health care expenses and to prevent financial considerations from discouraging ongoing health care utilization to the detriment of patient health. Our setting, which offers rich data on utilization from a closed network and quasi-experimental variation in program approval, provides an ideal opportunity to study the health care utilization ef- 
fects of a representative financial assistance program. ${ }^{12}$

The on-impact effects of the financial assistance program on health care utilization are proportionally similar to the effects of Medicaid on health care utilization. Appendix Table A7 summarizes the IV effects from quarter 1 to the most closely related estimates from the Oregon Health Insurance Experiment (Finkelstein et al., 2012; Taubman et al., 2014). Relative to the mean for applicants above the threshold (350-450\% of FPL), the financial assistance program caused a $20.0 \%$ increase in the likelihood of an ambulatory visit, $58.1 \%$ increase in the likelihood of an inpatient encounter, $52.8 \%$ increase in the likelihood of an emergency department visit, and a $23.6 \%$ increase in prescription drug days supplied. Based on the Oregon experiment, Medicaid caused a 36.9\% increase in the number of outpatient visits (comparable to ambulatory visits), 10.7\% increase in the likelihood of an inpatient encounter, $20.3 \%$ increase in the likelihood of an emergency department visit, and a $15.0 \%$ increase in the likelihood of filling a prescription.

A key difference is that while the impacts of Medicaid are based on averages a year and a half after Medicaid uptake, the impacts of the financial assistance program fade out by the third quarter after program approval. Thus, the cumulative impact of the financial assistance program over a year-and-a-half period are smaller than those from Medicaid. To a certain extent, the transitory impact of the financial assistance program is not surprising. The program is designed to provide one-time debt relief and elimination of cost sharing for 6 to 12 months. ${ }^{13}$ Applicants may be patients for whom the cost-sharing reductions provided by the financial assistance program has a particularly large effect (i.e., a version of "selection on moral hazard" documented by Einav et al. (2013)).

Our findings of increased abnormal test results for treatment-sensitive conditions (heart disease and diabetes), and increased prescription drug utilization for chronic health conditions (cholesterol, diabetes) and depression, indicate that at least some of the increase in health care utilization caused by the financial assistance program is of high value. These results are consistent with an emerging set of evidence that consumer cost-sharing has

\footnotetext{
${ }^{12}$ While our research design allows us to credibly estimate the impact of Kaiser's financial assistance program, which bundles debt relief and cost-sharing reductions; it does not allow us to separately estimate the price and wealth effects of the program. Our results are nonetheless relevant to financial assistance policies more generally, given that many hospitals' programs are similarly constructed (see Table 1).

${ }^{13}$ We do not find any differential fade-out for applicants with 6- versus 12 -month reductions in cost sharing.
} 
detrimental impacts on the use of high-value care (Chandra et al., 2010; Brot-Goldberg et al., 2017). Indeed, our findings of increased high-value utilization is especially notable given that $88 \%$ of our sample has insurance coverage. While the effects of financial assistance on the insured is of stand-alone interest - given increasing cost-sharing and the $\$ 6$ billion in charity care currently provided to the insured - it is reasonable to project that the effects of financial assistance are even larger for uninsured patients.

\section{Conclusion}

This study uses a regression discontinuity design to estimate the impact of financial assistance programs on health care utilization. Financial assistance, in the form of debt forgiveness and reduced cost-sharing, has large on-impact effects on health care utilization, although these effects largely fade out within 3 quarters after program receipt. Financial assistance also increases the likelihood of abnormal test results and drug utilization for treatment-sensitive conditions, which is suggestive of increases in high-value care that could translate into improvements in health.

Given the intention of these programs to reduce barriers to care, our findings should be of interest to hospitals, which design and implement these programs, and patient advocates, who help patients apply for financial assistance. Our results are also relevant to the ongoing debate surrounding the $\$ 16$ billion spent on charity care by non-profit hospitals annually, which partly justifies the large tax exemptions granted to these hospitals (Bai et al., 2021). Our results are relevant to efforts at the state and federal level to expand financial assistance, and are broadly related to debates about expanding health insurance, for which hospital financial assistance programs are a substitute (Garthwaite et al., 2018).

The analysis in our paper takes the set of applicants to the financial assistance program as given. However, hospitals may under-promote their financial assistance programs, and potential applicants may be deterred by burdensome documentation requirements. ${ }^{14} \mathrm{Un}$ derstanding the application process and program take-up is an important area for future work.

\footnotetext{
${ }^{14}$ See, for example, https://www.wsj.com/articles/medical-debt-charity-to-buy-wipeout-278-million-of-patients-hospital-bills-11623762001?st=pa8wazovx3vsstn\& reflink=desktopwebshare_permalink
} 


\section{References}

Akinyemiju, Tomi, and Justin Xavier Moore. 2016. “Data on burden of comorbidities in the United States and Medicaid expansion status." Data in Brief, 8: 120-122.

Bai, Ge, Hossein Zare, Matthew D. Eisenberg, Daniel Polsky, and Gerard F. Anderson. 2021. "Analysis suggests government and nonprofit hospitals' charity care is not aligned with their favorable tax treatment: Study examines government and nonprofit hospital charity care expenses compared to charity care obligations arising from the organizations' favorable tax treatment." Health Affairs, 40(4): 629-636.

Brot-Goldberg, Zarek C., Amitabh Chandra, Benjamin R. Handel, and Jonathan T. Kolstad. 2017. "What does a deductible do? The impact of cost-sharing on health care prices, quantities, and spending dynamics." The Quarterly Journal of Economics, 132(3): 12611318 .

Calonico, Sebastian, Matias D. Cattaneo, and Rocio Titiunik. 2014. "Robust nonparametric confidence intervals for regression-discontinuity designs." Econometrica, 82(6): 22952326.

Camilleri, Susan. 2018. "The ACA Medicaid expansion, disproportionate share hospitals, and uncompensated care." Health Services Research, 53(3): 1562-1580.

Cattaneo, Matias D, Michael Jansson, and Xinwei Ma. 2020. "Simple local polynomial density estimators." Journal of the American Statistical Association, 115(531): 1449-1455.

Chaiyachati, Krisda H., Mingyu Qi, and Rachel M. Werner. 2020. “Nonprofit Hospital community benefit spending and readmission rates." Population Health Management, 23(1): 85-91.

Chandra, Amitabh, Jonathan Gruber, and Robin McKnight. 2010. "Patient cost-sharing and hospitalization offsets in the elderly." American Economic Review, 100(1): 193-213. 
Conner, Douglas A., Arne Beck, Christina Clarke, Leslie Wright, Komal Narwaney, and Neysa W. Bermingham. 2013. "Quality and cost evaluation of a medical financial assistance program." The Permanente Journal, 17(1): 31.

Cunningham, Peter J., and Ha T. Tu. 1997. “Trends: A changing picture of uncompensated care." Health Affairs, 16(4): 167-175.

Dranove, David, Craig Garthwaite, and Christopher Ody. 2016. "Uncompensated care decreased at hospitals in Medicaid expansion states but not at hospitals in nonexpansion states." Health Affairs, 35(8): 1471-1479.

Einav, Liran, Amy Finkelstein, Stephen P. Ryan, Paul Schrimpf, and Mark R. Cullen. 2013. "Selection on moral hazard in health insurance." American Economic Review, 103(1): 178-219.

Felder, Tisha M., Lincy S. Lal, Charles L. Bennett, Frank Hung, and Luisa Franzini. 2011. “Cancer patients' use of pharmaceutical patient assistance programs in the outpatient pharmacy at a large tertiary cancer center." Community Oncology, 8(6): 279.

Finkelstein, Amy, Sarah Taubman, Bill Wright, Mira Bernstein, Jonathan Gruber, Joseph P. Newhouse, Heidi Allen, Katherine Baicker, and Oregon Health Study Group. 2012. "The Oregon Health Insurance Experiment: Evidence from the first year." The Quarterly Journal of Economics, 127(3): 1057-1106.

Fryar, Cheryl D., Deanna Kruszan-Moran, Qiuping Gu, and Cynthia L. Ogden. 2018. "Mean body weight, weight, waist circumference, and body mass index among adults: United States, 1999-2000 through 2015-2016."

Garthwaite, Craig, Tal Gross, and Matthew J. Notowidigdo. 2018. "Hospitals as insurers of last resort." American Economic Journal: Applied Economics, 10(1): 1-39.

Herring, Bradley, Darrell Gaskin, Hossein Zare, and Gerard Anderson. 2018. "Comparing the value of nonprofit hospitals' tax exemption to their community benefits." INQUIRY: The Journal of Health Care Organization, Provision, and Financing, 55: 0046958017751970. 
International Expert Committee. 2009. “International Expert Committee report on the role of the A1C assay in the diagnosis of diabetes." Diabetes Care, 32(7): 1327-1334.

IRS. n.d.. "Charitable Hospitals - General requirements for tax-exemption under Section 501(c)(3)."

James, Julia. 2016. “Health policy brief: Nonprofit Hospitals' community benefit requirements." Health Affairs.

Ma, Hongbao, and Kuan-Jiunn Shieh. 2006. "Cholesterol and human health." The Journal of American Science, 2(1): 46-50.

Mann, Joyce M., Glenn A. Melnick, Anil Bamezai, and Jack Zwanziger. 1997. “A profile of uncompensated hospital care, 1983-1995." Health Affairs, 16(4): 223-232.

McCrary, Justin. 2008. "Manipulation of the running variable in the regression discontinuity design: A density test." Journal of Econometrics, 142(2): 698-714.

National Center for Health Statistics. 2021. "National Center for Health Statistics. Health, United States, 2019: Table 44."

\section{Paul, Christine, Allison Boyes, Alix Hall, Alessandra Bisquera, Annie Miller, and Lorna} O'Brien. 2016. “The impact of cancer diagnosis and treatment on employment, income, treatment decisions and financial assistance and their relationship to socioeconomic and disease factors." Supportive Care in Cancer, 24(11): 4739-4746.

Roth, Luke, Jessica Naber, Luke Metz, and Nina Nikolova. 2021. "Hospital care for the uninsured in the United States: An analysis of national data sources."

Semin, Jessica N., David Palm, Lynette M. Smith, and Sarah Ruttle. 2020. “Understanding breast cancer survivors' financial burden and distress after financial assistance." Supportive Care in Cancer, 1-8.

Singh, Simone R., Gary J. Young, Shoou-Yih Daniel Lee, Paula H. Song, and Jeffrey A. Alexander. 2015. "Analysis of hospital community benefit expenditures' alignment with 
community health needs: Evidence from a national investigation of tax-exempt hospitals." American Journal of Public Health, 105(5): 914-921.

Somerville, Martha H. 2012. "Community benefit in context: Origins and Evolution-ACA Section 9007."

Spencer, Jennifer C., Cleo A. Samuel, Donald L. Rosenstein, Katherine E. Reeder-Hayes, Michelle L. Manning, Jean B. Sellers, and Stephanie B. Wheeler. 2018. "Oncology navigators' perceptions of cancer-related financial burden and financial assistance resources." Supportive Care in Cancer, 26(4): 1315-1321.

Stark, Andrea Bopp. 2020. “An ounce of prevention: A review of hospital financial assistance policies in the States."

Starr, Paul. 2008. The social transformation of American medicine: The rise of a sovereign profession and the making of a vast industry. New York:Basic Books.

Taubman, Sarah L., Heidi L. Allen, Bill J. Wright, Katherine Baicker, and Amy N Finkelstein. 2014. “Medicaid increases emergency-department use: Evidence from Oregon's Health Insurance Experiment." Science, 343(6168): 263-268.

Young, Gary J., Chia-Hung Chou, Jeffrey Alexander, Shoou-Yih Daniel Lee, and Eli Raver. 2013. "Provision of community benefits by tax-exempt US hospitals." New England Journal of Medicine, 368(16): 1519-1527.

Zullig, Leah L., Steven Wolf, Lisa Vlastelica, Veena Shankaran, and S.Yousuf Zafar. 2017. "The role of patient financial assistance programs in reducing costs for cancer patients." Journal of Managed Care E Specialty Pharmacy, 23(4): 407-411. 


\section{Table 1: Hospital Financial Assistance Policies}

\begin{tabular}{|c|c|c|c|}
\hline Health System & $\begin{array}{l}\text { Number } \\
\text { of } \\
\text { Hospitals* }\end{array}$ & Eligibility Criteria $^{\dagger}$ & Benefits \\
\hline \multicolumn{4}{|c|}{ Panel A. Largest For-Profit Health Systems } \\
\hline $\begin{array}{l}\text { HCA } \\
\text { Healthcare }\end{array}$ & 185 & $\begin{array}{l}\text { Income }<200 \% \text { FPL } \\
\text { Income between } 200 \text { and } 400 \% \\
\text { FPL }\end{array}$ & $\begin{array}{l}100 \% \text { write-off of emergency services costs } \\
\text { Cap out-of-pocket balances at } 4 \% \text { of annual income } \\
\text { using a sliding scale }\end{array}$ \\
\hline $\begin{array}{l}\text { Community } \\
\text { Health } \\
\text { Systems } \\
\text { Tenet Healthcare }\end{array}$ & 105 & $\begin{array}{l}\text { Income }<200 \% \text { FPL } \\
\text { Income between } 201 \text { and } 301 \% \\
\text { FPL } \\
\text { Income }<200 \% \text { FPL }\end{array}$ & $\begin{array}{l}\text { Receive care for free } \\
\text { Receive care discounted to the amount generally } \\
\text { billed to Medicare } \\
100 \% \text { charity care discount }\end{array}$ \\
\hline $\begin{array}{l}\text { Universal } \\
\text { Health } \\
\text { Services }\end{array}$ & 26 & $\begin{array}{l}\text { Income }<200 \% \text { FPL } \\
\text { Income between } 201 \text { and } 250 \% \\
\text { FPL } \\
\text { Income between } 251 \text { and } 300 \% \\
\text { FPL }\end{array}$ & $\begin{array}{l}100 \% \text { discount off gross charges } \\
83.5 \% \text { discount off gross charges } \\
67 \% \text { discount off gross charges }\end{array}$ \\
\hline \multicolumn{4}{|c|}{ Panel B. Largest Non-Profit Health Systems } \\
\hline $\begin{array}{l}\text { Ascension } \\
\text { Health }\end{array}$ & 151 & $\begin{array}{l}\text { Income }<=250 \% \text { FPL } \\
\text { Income between } 250 \text { and } 350 \% \\
\text { FPL } \\
\text { Income between } 351 \text { and } 400 \% \\
\text { FPL }\end{array}$ & $\begin{array}{l}100 \% \text { discount off patient responsibility amounts } \\
75 \% \text { discount off patient responsibility amounts } \\
67 \% \text { discount off patient responsibility amounts }\end{array}$ \\
\hline Trinity Health & 92 & Income below $250 \%$ FPL & $100 \%$ discount on patient financial obligations \\
\hline $\begin{array}{l}\text { Providence } \\
\text { Health }\end{array}$ & 51 & $\begin{array}{l}\text { Income }<=300 \% \text { FPL } \\
\text { Income between } 301 \text { and 350\% } \\
\text { FPL }\end{array}$ & $\begin{array}{l}100 \% \text { write-off on patient responsibility amounts } \\
75 \% \text { discount off patient responsibility amounts }\end{array}$ \\
\hline $\begin{array}{l}\text { Atrium } \\
\text { Health }\end{array}$ & 50 & $\begin{array}{l}\text { Income }<=200 \% \text { FPL } \\
\text { Income between } 201 \text { and 300\% } \\
\text { FPL } \\
\text { Income between } 301 \text { and } 400 \% \\
\text { FPL }\end{array}$ & $\begin{array}{l}100 \% \text { discount on eligible services for } 180 \text { days } \\
75 \% \text { discount on eligible services for } 180 \text { days } \\
50 \% \text { discount on eligible services for } 180 \text { days }\end{array}$ \\
\hline$\underset{\S}{\text { Kaiser Permanente }}$ & 39 & Income $<=350 \% \mathrm{FPL}$ & $\begin{array}{l}100 \% \text { discount on patient responsibility bills; may also } \\
\text { include an eligibility period for follow up services }\end{array}$ \\
\hline
\end{tabular}

* Based on information as of July 2019. See Appendix A for details for an expanded list and details on the construction of this table.

t The table lists income-based eligibility criteria only. The exact terms for each financial assistance program may include other eligibility requirements such as patient insurance status, medical expenditure incurred, and asset level, which in turn might be associated with different benefit terms.

$\ddagger$ Eligibility criteria vary by state and by hospital. The policy here pertains to Lourdes Hospital in Binghamton, NY.

$\S$ Eligibility criteria vary by region. The policy here pertains to Kaiser Permenente Northern California. 
Table 2: Summary Statistics and Covariate Balance

\begin{tabular}{|c|c|c|c|c|c|}
\hline & \multicolumn{3}{|c|}{ Sample Mean } & \multicolumn{2}{|c|}{ Discontinuity } \\
\hline & $\begin{array}{r}150-550 \% \text { FPL } \\
(1)\end{array}$ & $\begin{array}{r}250-350 \% \text { FPL } \\
(2)\end{array}$ & $\begin{array}{r}350-450 \% \text { FPL } \\
\text { (3) }\end{array}$ & $\begin{array}{r}\text { RD Estimate } \\
(4)\end{array}$ & $p$-value \\
\hline \multicolumn{6}{|l|}{ Demographics at Application } \\
\hline Family Income (\$) & 40299.29 & 49355.72 & 65714.77 & -197.67 & 0.82 \\
\hline Family Size & 2.15 & 2.19 & 2.17 & -0.00 & 0.97 \\
\hline White (\%) & 50.65 & 50.99 & 48.24 & -0.00 & 0.85 \\
\hline Male (\%) & 42.65 & 44.38 & 48.43 & -0.04 & 0.13 \\
\hline Age & 57.77 & 56.57 & 55.13 & -0.42 & 0.71 \\
\hline Elixhauser Comorbidity Index ${ }^{\dagger}$ & 3.52 & 3.45 & 3.36 & 0.13 & 0.43 \\
\hline Body Mass Index (BMI) & 29.05 & 29.27 & 29.23 & 0.34 & 0.35 \\
\hline Ever Smoked (\%) & 42.34 & 41.63 & 41.80 & -0.02 & 0.46 \\
\hline \multicolumn{6}{|l|}{ Insurance and Cost in Quarter -1 $1^{\ddagger}$} \\
\hline Insured (\%) & 88.12 & 89.48 & 90.47 & -0.01 & 0.73 \\
\hline Medicare Advantage (\%) & 52.40 & 49.76 & 46.23 & -0.01 & 0.67 \\
\hline Total Cost $(\$)$ & 6094.89 & 6461.90 & 6884.35 & -132.03 & 0.92 \\
\hline \multicolumn{6}{|l|}{ Key Outcomes in Quarter -1 } \\
\hline Any Encounter (\%) & 67.05 & 67.98 & 69.11 & -0.00 & 0.93 \\
\hline Any Ambulatory Encounter (\%) & 65.36 & 66.43 & 67.78 & -0.00 & 0.93 \\
\hline Any Inpatient Encounter (\%) & 7.30 & 7.45 & 7.72 & -0.00 & 0.92 \\
\hline Any Emergency Department Encounter (\%) & 15.24 & 14.90 & 14.01 & 0.01 & 0.37 \\
\hline Prescription Drug Days Supplied § & 132.50 & 133.83 & 132.60 & -3.77 & 0.64 \\
\hline Any Test Record $(\%)$ & 21.70 & 21.88 & 24.02 & -0.02 & 0.26 \\
\hline Any Abnormal Test Result (Unconditional) (\%) & 11.61 & 12.18 & 12.39 & 0.00 & 0.98 \\
\hline Any Abnormal Test Result Conditional on Test (\%) & 53.48 & 55.66 & 51.59 & 0.06 & 0.28 \\
\hline
\end{tabular}

Note: Quarter -1 corresponds to event months $-3,-4$, and -5 relative to the quarter of application decision. The income eligibility cutoff is $350 \%$ of FPL. Column 1 shows means for the baseline sample with income between $150 \%$ and $550 \%$ of FPL; columns 2 and 3 show means for applicants within 100 percentage points of the $350 \%$ FPL threshold. Columns 4 and 5 report coefficient estimates and p-values on an indicator for income below the $350 \%$ of FPL threshold from our baseline regression discontinuity specification (equation 1).

${ }^{\dagger}$ Calculated for the 12 months prior to program application.

‡ The insurance coverage variables are indicators for being insured in all months of quarter -1 .

$\S$ Winsorized at the 95th percentile. 
Figure 1: Distribution of Applicant Income and First Stage
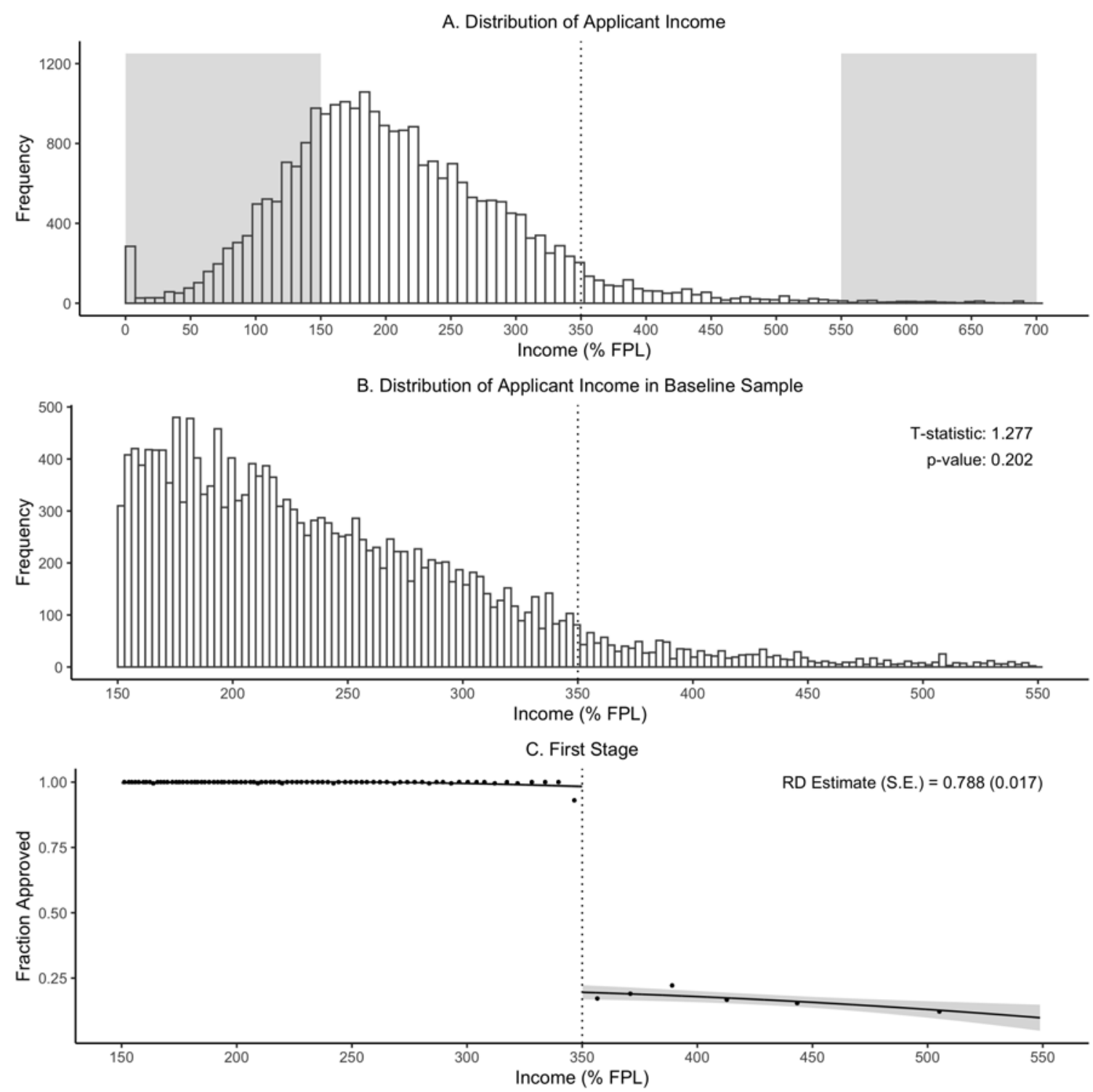

Note: Panel A shows the distribution of applicant income, with the gray region showing applicants outside of our baseline sample (150-550\% of FPL). Panel B shows the distribution of income for the baseline sample and reports the t-statistic and p-value from the manipulation test proposed by Cattaneo, Jansson, and Ma (2020). Panel C shows the first stage effect on approval at 350\% of FPL. Dots show the mean approval rate within equal-frequency income bins. Solid lines are fitted values from a second-order polynomial; gray bands show a $95 \%$ confidence interval. 


\section{Figure 2: RD Estimates for Quarter 1}
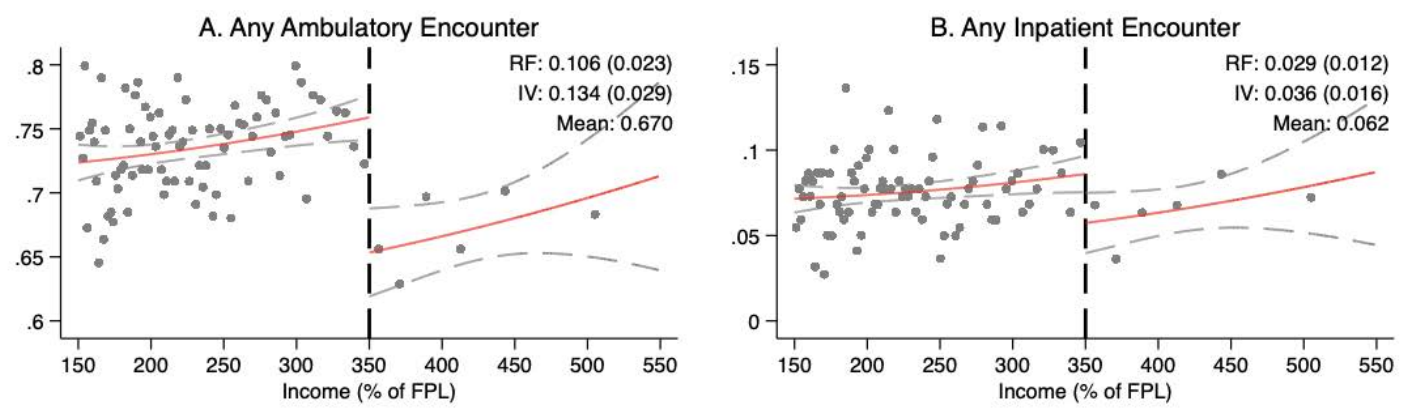

\section{Any Emergency Department Encounter}
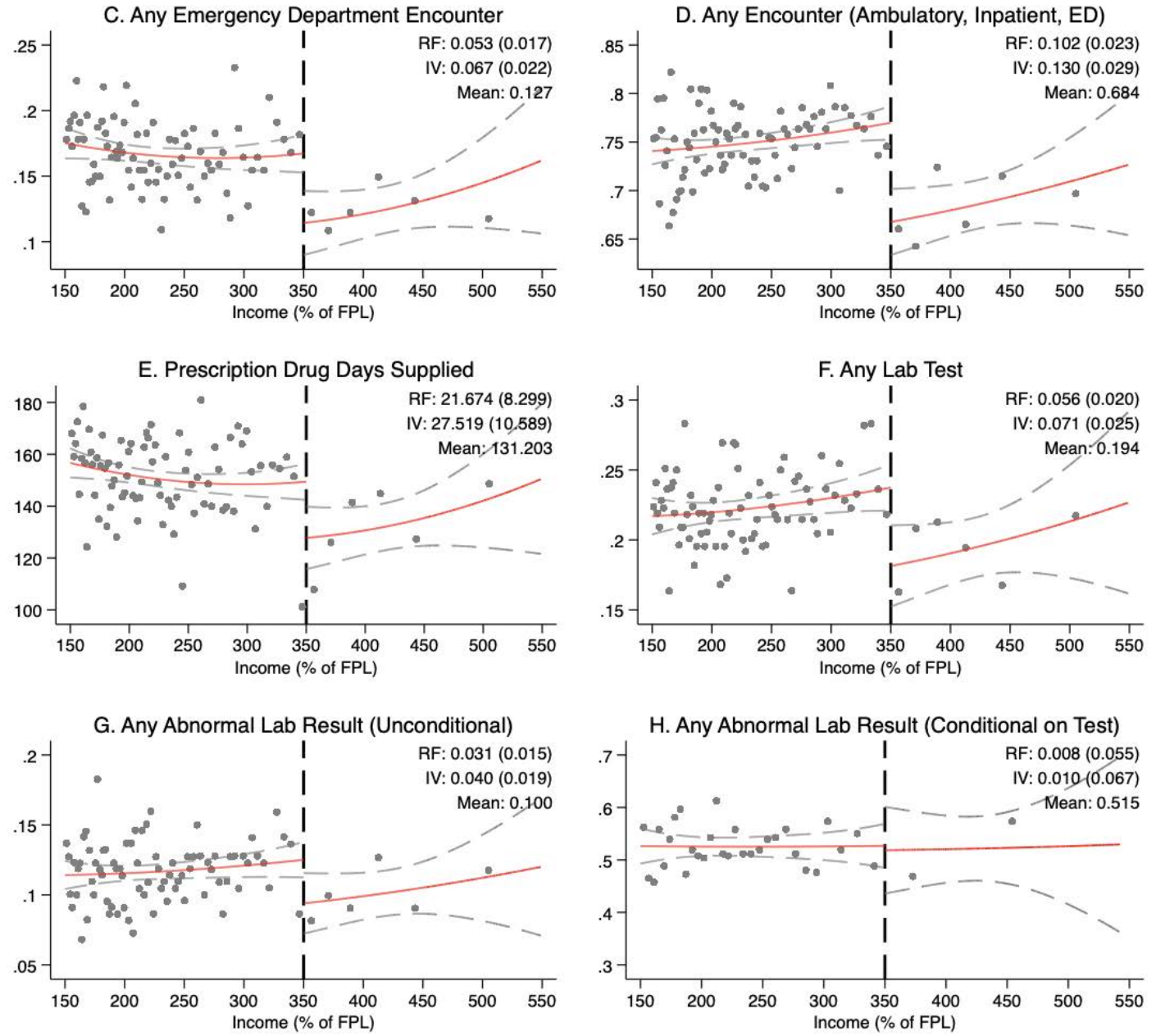

Note: Figure shows regression discontinuity plots of the impact of financial assistance in the first quarter after the application decision. Dots show the mean of the outcome for 85 equal-frequency bins (220 applicants per bin, except for Panel $\mathrm{G}$ where there are 130 applicants per bin). Solid lines show fitted values from a second-order polynomial; dashed lines show 95\% confidence intervals. For each outcome, we also report the RD and IV estimates, their standard errors, and the mean of the outcome for applicants with an income of $350-450 \%$ of FPL (i.e., the "control group" mean). Prescription Drug Days Supplied is winsorized at the 95th percentile. 
Figure 3: RD Estimates for Each Quarter
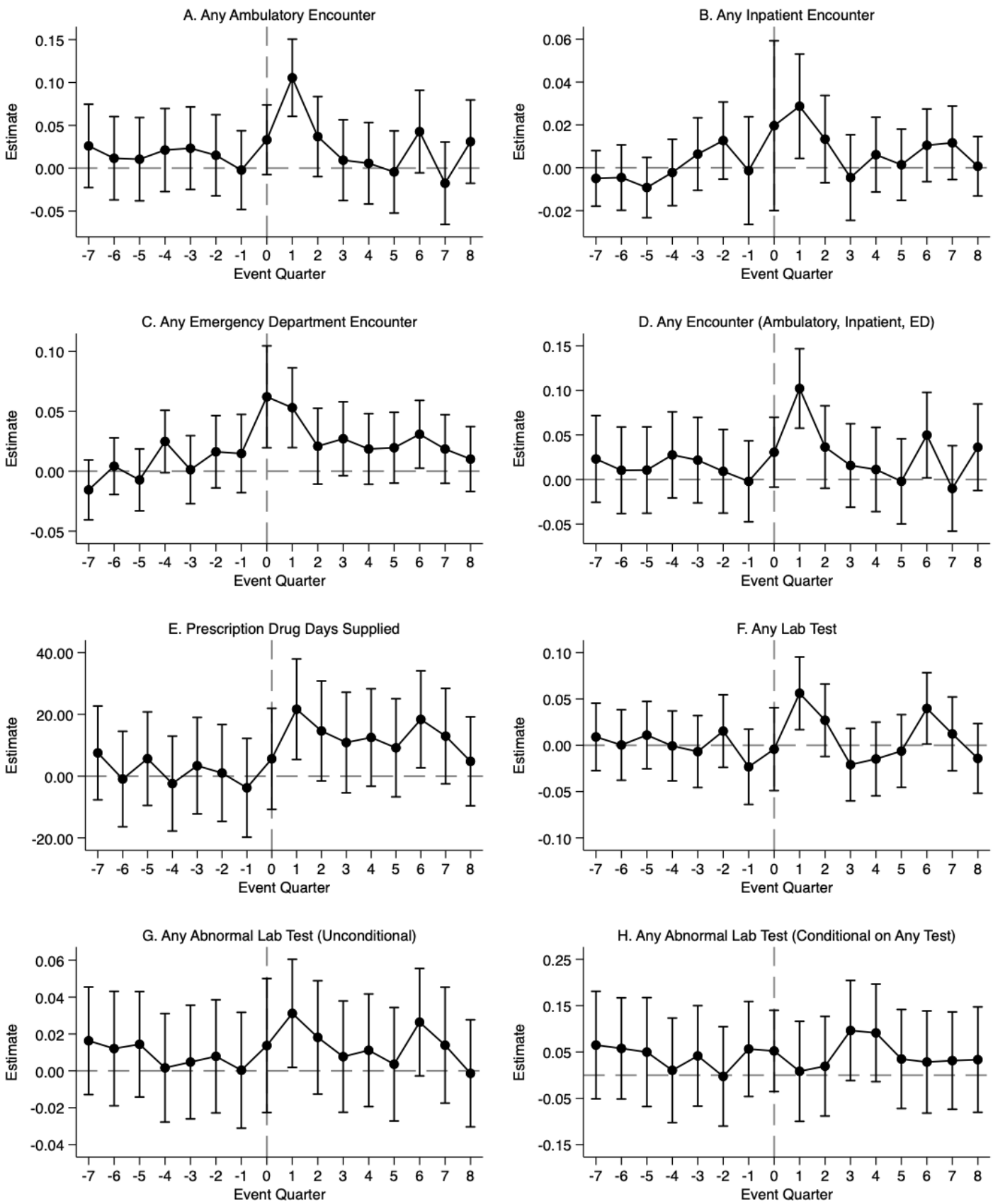

Note: Plots show regression discontinuity estimates, and the corresponding $95 \%$ confidence intervals, of the impact of financial assistance for quarters $t \in[-7,8]$. Event quarter 0 corresponds to event months $0,-1$, and -2 relative to the month of the application decision. Prescription Drug Days Supplied is winsorized at the 95th percentile. 


\title{
The Impact of Financial Assistance Programs on Health Care Utilization
}

\author{
Online Appendix
}

\author{
Alyce Adams \\ Raymond Kluender \\ Neale Mahoney \\ Jinglin Wang \\ Francis Wong \\ Wesley Yin
}

\section{A Hospital Financial Assistance Policies}

We focus on the 40 largest health systems by number of hospitals as of July 2019, compiled by Becker's Hospital Review (www.beckershospitalreview.com/largesthospitals-and-health-systems-in-america-2019). To determine whether a health system has a financial assistance program, we search on the health system's organization website using keywords such as financial assistance and charity care. For eligibility criteria and benefits, we refer to the most recent financial assistance/charity care policy documents available on the organization's website. We record only income-based eligibility criteria and use the organization's own language to describe the benefits (with small modifications for succinctness). To determine whether a health system is not-for-profit, we refer primarily to the organization's website (or other sources found via internet search if such information is not available on the organization's website).

\section{B Manipulation Tests}

Appendix Table A2 reports results from manipulation tests of the density of applicants around the 350\% FPL threshold. For reference, the first column reports the coefficient on an indicator for income less than the 350\% FPL threshold from the first stage regression (equation 2). The second column reports results from the manipulation test proposed by Cattaneo et al. (2020, henceforth CJM) using the recommended second-order polynomial 
with bandwidths of $31.48 \mathrm{pp}$ and $40.25 \mathrm{pp}$ below and above the discontinuity, respectively. The $\mathrm{p}$-value for the test statistic of 0.202 fails to reject the null of no manipulation. The third column reports results from the manipulation test proposed in McCrary (2008) using the recommended bin size (1.05 pp) and bandwidth (80.31 pp). The p-value of for this test rejects the null of no manipulation.

Because the result of the McCrary test conflicts with that from CJM, and because excess mass below the cutoff is not evident in visual inspection of the density (Figure 1), we assess the performance of both methods by implementing these tests at placebo thresholds throughout the distribution of income in our sample (i.e. at various points that do not correspond to any relevant program cutoff). Our baseline sample is comprised of applicants with an income of +/- 200\% FPL around the 350\% FPL threshold. We construct placebo thresholds at 1\% intervals for the 301 points between $200 \%$ of FPL and $500 \%$ of FPL, and implement the CJM and McCrary tests on samples restricted to applicants +/$200 \%$ FPL from these placebo cutoffs. As we do above, we use the recommended bin sizes and bandwidths for all of these exercises.

Appendix Figure A3 plots the resulting p-values of the test statistics against the placebo thresholds from this exercise. The CJM test (Panel A) is moderately prone to over-rejecting the null of no manipulation, with p-values of less than 0.05 for $16.6 \%$ of placebo thresholds. In comparison, the McCrary test (Panel B) is much more biased towards over-rejection, rejecting the null with a p-value below 0.05 in $40.5 \%$ for placebo thresholds. Based on this simulation, we conclude that the McCrary test is not well-suited to our environment. We view the fact that the CJM moderately over-rejects on average but fails to reject at the true $350 \%$ threshold as fairly strong evidence in support of the research design. 
Table A1: Financial Assistance Policies

\begin{tabular}{|c|c|c|c|c|}
\hline Rank & Health System & $\begin{array}{l}\text { Number of } \\
\text { Hospitals }\end{array}$ & Program eligibility & Benefit \\
\hline \multirow[t]{2}{*}{1} & HCA Healthcare & 185 & Income $<200 \%$ FPL & $100 \%$ write-off of costs related to emergency services \\
\hline & & & Income between 200 and $400 \%$ FPL & $\begin{array}{l}\text { Out-of-pocket balances are capped at } 4 \% \text { of annual income using a sliding } \\
\text { scale. }\end{array}$ \\
\hline \multirow[t]{3}{*}{2} & Ascension Health & 151 & Income $<=250 \% \mathrm{FPL}$ & $100 \%$ discount off patient responsibility amounts \\
\hline & & & Income between 250 and $350 \%$ FPL & $75 \%$ discount off patient responsibility amounts \\
\hline & & & Income between 351 and 400\% FPL & $67 \%$ discount off patient responsibility amounts \\
\hline \multirow[t]{2}{*}{4} & Community Health Sys- & 142 & Income $<200 \% \mathrm{FPL}$ & Receive care for free \\
\hline & & & Income between $201 \%$ and $301 \%$ FPL & $\begin{array}{l}\text { Receive care discounted to the amount generally billed to Medicare pa- } \\
\text { tients for such services. }\end{array}$ \\
\hline 5 & Trinity Health & 92 & Income $<250 \% \mathrm{FPL}$ & $100 \%$ discount on patient financial obligations \\
\hline 7 & Tenet Healthcare & 65 & Income below $200 \% \mathrm{FPL}$ & $100 \%$ charity care discount \\
\hline \multirow[t]{2}{*}{9} & Providence Health & 51 & Income $<=300 \% \mathrm{FPL}$ & $100 \%$ write-off on patient responsibility amounts \\
\hline & & & Income between 301 and 350\% FPL & $75 \%$ discount from original charges on patient responsibility amounts \\
\hline \multirow[t]{3}{*}{10} & Atrium Health & 50 & Income $<=200 \%$ of FPL & $100 \%$ discount on eligible services for 180 days \\
\hline & & & Income between 201 and 300\% FPL & $75 \%$ discount on eligible services for 180 days \\
\hline & & & Income between 301 and 400\% FPL & $50 \%$ discount on eligible services for 180 days \\
\hline 11 & AdventHealth & 50 & Income $<=200 \% \mathrm{FPL}$ & $100 \%$ write-off of medical bills \\
\hline
\end{tabular}


Table A1 - Continued from previous page

\begin{tabular}{|c|c|c|c|c|}
\hline Rank & Health System & $\begin{array}{l}\text { Number of } \\
\text { Hospitals }\end{array}$ & Program eligibility & Benefit \\
\hline \multirow[t]{3}{*}{12} & Baylor Scott \& White & 48 & Income $<200 \%$ FPL & $100 \%$ discount on outstanding patient account balances \\
\hline & Health & & & \\
\hline & & & Income between 200 and 500\% FPL & $\begin{array}{l}\text { Patient owes the lesser of the patient's account balance or } 10 \% \text { of the pa- } \\
\text { tient's gross charges no greater than the Amount Generally Billed }\end{array}$ \\
\hline \multirow[t]{3}{*}{13} & Bon Secours & 48 & Income $<=200 \% \mathrm{FPL}$ & $100 \%$ financial assistance \\
\hline & Health & & & \\
\hline & & & Income between 201 and 400\% FPL & Receive discounted care based on a sliding scale on a regional basis \\
\hline \multirow[t]{2}{*}{15} & Sanford Health & 44 & Income $<=225 \% \mathrm{FPL}$ & Complete forgiveness of patient due balance \\
\hline & & & Income between 226 and 375\% FPL & $\begin{array}{l}\text { Partial reduction of the amount of the balance outstanding such that the } \\
\text { remaining balance will be no greater than the amount generally billed }\end{array}$ \\
\hline \multirow[t]{3}{*}{16} & Mercy & 41 & Income $<200 \%$ FPL & 100\% hospital and physician discount \\
\hline & & & Income between $251-250 \%$ & $80 \%$ hospital discount and $70 \%$ physician discount \\
\hline & & & Income between $251-300 \%$ & $74 \%$ hospital discount and $50 \%$ physician discount \\
\hline \multirow[t]{3}{*}{17} & UPMC & 40 & Income $<250 \% \mathrm{FPL}$ & Receive $100 \%$ discounted charity care \\
\hline & & & Income between $251-300 \%$ & Receive care at $80 \%$ discount rate \\
\hline & & & Income between $301-400 \%$ & Receive care at $70 \%$ discount rate \\
\hline 18 & Kaiser Permanente & 39 & Income $<=350 \% \mathrm{FPL}$ & $\begin{array}{l}100 \% \text { discount on patient responsibility; may also include an eligibility } \\
\text { period for follow up services }\end{array}$ \\
\hline 19 & MercyOne & 39 & Income $<=350 \% \mathrm{FPL}$ & Free care for medically-necessary services \\
\hline 21 & Christus Health & 35 & Income below $300 \%$ FPL & $100 \%$ charity care discount off patient responsibility amounts \\
\hline
\end{tabular}


Table A1 - Continued from previous page

\begin{tabular}{|c|c|c|c|c|}
\hline Rank & Health System & $\begin{array}{l}\text { Number of } \\
\text { Hospitals }\end{array}$ & Program eligibility & Benefit \\
\hline & & & Income between $300 \%$ and $401 \% \mathrm{FPL}$ & Patient gross charges capped at the Amount Generally Billed to Medicare \\
\hline \multirow[t]{3}{*}{22} & Avera Health & 33 & Income below $150 \%$ FPL & $100 \%$ forgiveness of charges for emergent or medically necessary care \\
\hline & & & Income between $150 \%$ and $400 \% \mathrm{FPL}$ & Up to $90 \%$ forgiveness of charges for emergent or medically necessary care \\
\hline & & & & based on a sliding scale \\
\hline \multirow[t]{3}{*}{24} & Great Plains Health Al- & 29 & Income $<=250 \% \mathrm{FPL}$ & Full write-off of charges \\
\hline & liance & & & \\
\hline & & & Income between $251 \%$ and $450 \%$ FPL & Up to $75 \%$ forgiveness of charges based on a sliding scale \\
\hline 25 & Texas Health Resources & 29 & Income $<=200 \% \mathrm{FPL}$ & $\begin{array}{l}\text { Discount equal to the due balance less any amount the patient is deemed } \\
\text { able to pay }\end{array}$ \\
\hline \multirow[t]{2}{*}{26} & Advocate Aurora Health & 28 & Income $<=250 \% \mathrm{FPL}$ & $100 \%$ financial assistance adjustment on patient responsibility amount \\
\hline & & & Income between $250 \%$ and $600 \% \mathrm{FPL}$ & Partial financial assistance adjustment \\
\hline \multirow[t]{6}{*}{27} & Banner Health & 28 & Income $<200 \%$ FPL & $100 \%$ discount off patient account for uninsured patients or balance after \\
\hline & & & & insurance in excess of $\$ 2500$ for insured patients \\
\hline & & & Income between $200 \%$ and $300 \% \mathrm{FPL}$ & $75 \%$ discount off AGB for uninsured patients or balance after insurance in \\
\hline & & & & excess of $\$ 2500$ for insured patients \\
\hline & & & Income between $300 \%$ and $400 \% \mathrm{FPL}$ & $50 \%$ discount off AGB for uninsured patients or balance after insurance in \\
\hline & & & & excess of $\$ 2500$ for insured patients \\
\hline \multirow[t]{2}{*}{30} & Universal Health Ser- & 26 & Income $<200 \%$ FPL & $100 \%$ discount off gross charges \\
\hline & & & Income between $201 \%$ and $250 \% \mathrm{FPL}$ & $83.5 \%$ discount off gross charges \\
\hline
\end{tabular}


Table A1 - Continued from previous page

\begin{tabular}{|c|c|c|c|c|}
\hline Rank & Health System & $\begin{array}{l}\text { Number of } \\
\text { Hospitals }\end{array}$ & Program eligibility & Benefit \\
\hline & & & Income between $251 \%$ and $300 \%$ FPL & $67 \%$ discount off gross charges \\
\hline \multirow[t]{2}{*}{31} & Intermountain Health- & 24 & Income below $200 \%$ FPL & Full assistance, minus a nominal patient responsibility per episode of care \\
\hline & & & Income between $200 \%$ and $500 \% \mathrm{FPL}$ & Partial financial assistance based on a sliding scale \\
\hline 32 & Sutter Health & 24 & Income $<400 \%$ FPL & Full charity care \\
\hline \multirow[t]{3}{*}{34} & Mayo Clinic Health Sys- & 23 & Income $<200 \% \mathrm{FPL}$ & $100 \%$ adjustment of the self-pay balance \\
\hline & tem & & & \\
\hline & & & Income between $200 \%$ and $400 \%$ FPL & $50 \%$ adjustment of the self-pay balance \\
\hline \multirow[t]{3}{*}{35} & Northwell Health & 23 & Income below $100 \% \mathrm{FPL}$ & Full financial assistance \\
\hline & & & Income between $101 \%$ and $500 \% \mathrm{FPL}$ & Partial Financial Assistance with the amount billable to the patient capped \\
\hline & & & & at the Amount Generally Billed to insured persons \\
\hline \multirow[t]{2}{*}{36} & SSM Health & 23 & Income $<200 \%$ FPL & $100 \%$ financial assistance discount \\
\hline & & & Income between $201 \%$ and $400 \%$ FPL & Partial financial assistance based on a sliding scale \\
\hline \multirow[t]{3}{*}{37} & Baptist & 22 & Income $<200 \% \mathrm{FPL}$ & $100 \%$ financial assistance discount \\
\hline & & & Income between 201 and 400\% FPL & Partial financial assistance based on a sliding scale \\
\hline & & & Income $>400 \% \mathrm{FPL}$ & Varies by facility \\
\hline \multirow[t]{3}{*}{38} & UnityPoint Health & 22 & Income $<200 \%$ FPL & $100 \%$ discount \\
\hline & & & Income between 201 and 400\% FPL & $\begin{array}{l}\text { Partial discount off the Amount Generally Billed to insured patients based } \\
\text { on a sliding scale }\end{array}$ \\
\hline & & & Income between 401 and $600 \%$ FPL & Amount Generally Billed to insured patients only \\
\hline
\end{tabular}


Table A1 - Continued from previous page

\begin{tabular}{|c|c|c|c|c|}
\hline Rank & Health System & $\begin{array}{l}\text { Number of } \\
\text { Hospitals }\end{array}$ & Program eligibility & Benefit \\
\hline \multirow[t]{2}{*}{39} & Ballad Health & 21 & Income $<225 \%$ FPL & $100 \%$ financial assistance \\
\hline & & & Income between $225 \%$ and $450 \% \mathrm{FPL}$ & $\begin{array}{l}\text { Partial discount on Amount Generally Billed charges based on a sliding } \\
\text { scale }\end{array}$ \\
\hline \multirow[t]{2}{*}{40} & $\begin{array}{l}\text { Hospital Sisters Health } \\
\text { System }\end{array}$ & 15 & Income $<200 \%$ FPL & $100 \%$ discount off patient account \\
\hline & & & $\begin{array}{l}\text { Income between } 201 \% \text { FPL and } 400 \% \text { FPL } \\
\text { (Wisconsin) or } 600 \% \text { FPL (Illinois) }\end{array}$ & Partial discount off patient account based on a sliding scale \\
\hline
\end{tabular}

Note: See Appendix Section A for details on the construction of this table. 
Table A2: First Stage and Manipulation Tests

\begin{tabular}{lrrr}
\hline & First Stage & CJM Test & McCrary Test \\
\hline Coef. & 0.7876 & 0.0003 & 0.4318 \\
Std. Err. & 0.0169 & 0.0002 & 0.0749 \\
Test Statistic & 46.6977 & 1.2767 & 5.7627 \\
P-value & 0.0000 & 0.2017 & 0.0000 \\
Obs. & 18672 & 18672 & 18672 \\
\hline
\end{tabular}

Note: Column 1 reports the coefficient on an indicator for income less than the $350 \%$ FPL threshold from the first stage regression (equation 2). Column 2 reports results from the Cattaneo, Jansson, and Ma (2020) manipulation test using the recommend second-order polynomial with bandwidths of $31.05 \mathrm{pp}$ and 39.30 pp below and above the discontinuity, respectively. Coef. is the difference between the local quadratic density estimators to either side of the cutoff; test statistic is the t-score. Column 3 reports results from a McCrary (2008) manipulation test using the recommended bin size (1.04 pp) and bandwidth (81.14 pp). 


\section{Table A3: RD Estimates for Quarter 1, Clinical Outcomes}

\begin{tabular}{|c|c|c|c|c|c|c|c|}
\hline & \multirow[b]{2}{*}{ Control Mean } & \multicolumn{3}{|c|}{ Reduced Form } & \multicolumn{3}{|c|}{ Instrumental Variables } \\
\hline & & Coef (SE) & $95 \% \mathrm{CI}$ & P-value & Coef (SE) & $95 \% \mathrm{CI}$ & P-value \\
\hline \multicolumn{8}{|l|}{ A. Cholesterol } \\
\hline Abnormal Cholesterol ${ }^{\dagger}$ & 0.027 & $\begin{array}{r}0.021 \\
(0.008)\end{array}$ & {$[0.006,0.036]$} & 0.007 & $\begin{array}{r}0.026 \\
(0.010)\end{array}$ & {$[0.007,0.046]$} & 0.007 \\
\hline Any Abnormal Cholesterol Drugs & 0.262 & $\begin{array}{r}0.038 \\
(0.022)\end{array}$ & {$[-0.004,0.081]$} & 0.079 & $\begin{array}{r}0.049 \\
(0.028)\end{array}$ & {$[-0.006,0.103]$} & 0.080 \\
\hline Days Supplied for Abnormal Cholesterol Drugs $\ddagger$ & 24.874 & $\begin{array}{r}3.353 \\
(2.077)\end{array}$ & {$[-0.717,7.423]$} & 0.106 & $\begin{array}{r}4.257 \\
(2.642)\end{array}$ & {$[-0.922,9.436]$} & 0.107 \\
\hline \multicolumn{8}{|l|}{ B. Diabetes } \\
\hline A1C Level $\geq 6.5$ & 0.070 & $\begin{array}{r}0.011 \\
(0.013)\end{array}$ & {$[-0.014,0.036]$} & 0.399 & $\begin{array}{r}0.014 \\
(0.016)\end{array}$ & {$[-0.018,0.046]$} & 0.399 \\
\hline Any Diabetes Drugs & 0.141 & $\begin{array}{r}0.029 \\
(0.017)\end{array}$ & {$[-0.004,0.063]$} & 0.087 & $\begin{array}{r}0.037 \\
(0.022)\end{array}$ & {$[-0.005,0.080]$} & 0.087 \\
\hline Days Supplied for Diabetes Drugs $\ddagger$ & 18.437 & $\begin{array}{r}5.146 \\
(2.477)\end{array}$ & {$[0.290,10.002]$} & 0.038 & $\begin{array}{r}6.533 \\
(3.150)\end{array}$ & {$[0.359,12.708]$} & 0.038 \\
\hline \multicolumn{8}{|l|}{ C. Depression } \\
\hline Any Antidepressants & 0.149 & $\begin{array}{r}0.044 \\
(0.018)\end{array}$ & {$[0.008,0.079]$} & 0.015 & $\begin{array}{r}0.055 \\
(0.023)\end{array}$ & {$[0.011,0.100]$} & 0.016 \\
\hline Days Supplied for Antidepressants $\ddagger$ & 14.211 & $\begin{array}{r}3.793 \\
(1.776)\end{array}$ & {$[0.311,7.275]$} & 0.033 & $\begin{array}{r}4.816 \\
(2.261)\end{array}$ & {$[0.384,9.248]$} & 0.033 \\
\hline \multicolumn{8}{|l|}{ D. Blood Pressure } \\
\hline Any Blood Pressure Drugs & 0.398 & $\begin{array}{r}0.030 \\
(0.024)\end{array}$ & {$[-0.018,0.077]$} & 0.219 & $\begin{array}{r}0.038 \\
(0.031)\end{array}$ & {$[-0.023,0.098]$} & 0.220 \\
\hline Days Supplied for Blood Pressure Drugs $\ddagger$ & 66.062 & $\begin{array}{r}9.691 \\
(4.762)\end{array}$ & {$[0.358,19.025]$} & 0.042 & $\begin{array}{r}12.305 \\
(6.069)\end{array}$ & [ 0.410,24.199] & 0.043 \\
\hline
\end{tabular}

Note: Table reports regression discontinuity estimates for quarter 1 with standard errors in parentheses.

+ Abnormal Cholesterol is defined as having either high total cholesterol or low HDL test results at any point in the given quarter. A high total cholesterol level is defined as $240 \mathrm{mg}$ per deciliter or higher for adults (age $18+)$ and $170 \mathrm{mg}$ per deciliter or higher for non-adults. A low HDL cholesterol level is defined as less than 40 mg per deciliter for adults or less than $45 \mathrm{mg}$ per deciliter for non-adults.

$\ddagger$ Winsorized at the 95th percentile.

Control mean is the mean for applicants with incomes between $350 \%$ and $450 \%$ of FPL. N $=18,672$

observations. 
Table A4: RD Estimates for Each Quarter

\begin{tabular}{|c|c|c|c|c|c|c|c|c|c|c|c|c|c|c|c|c|}
\hline \multirow[b]{2}{*}{ Quarter } & \multicolumn{2}{|c|}{ Ambulatory } & \multicolumn{2}{|c|}{ Inpatient } & \multicolumn{2}{|c|}{ ED } & \multicolumn{2}{|c|}{ Any Encounter } & \multicolumn{2}{|c|}{$R X$} & \multicolumn{2}{|c|}{ Any Lab } & \multicolumn{2}{|c|}{ Unconditional Lab } & \multicolumn{2}{|c|}{ Conditional Lab } \\
\hline & Coef & P Value & Coef & P Value & Coef & P Value & Coef & P Value & Coef & P Value & Coef & P Value & Coef & P Value & Coef & P Value \\
\hline-7 & $\begin{array}{c}0.026 \\
(0.025)\end{array}$ & 0.295 & $\begin{array}{l}-0.005 \\
(0.007)\end{array}$ & 0.454 & $\begin{array}{l}-0.016 \\
(0.013)\end{array}$ & 0.223 & $\begin{array}{c}0.023 \\
(0.025)\end{array}$ & 0.352 & $\begin{array}{c}7.531 \\
(7.752)\end{array}$ & 0.331 & $\begin{array}{c}0.009 \\
(0.019)\end{array}$ & 0.627 & $\begin{array}{c}0.016 \\
(0.015)\end{array}$ & 0.273 & $\begin{array}{c}0.065 \\
(0.059)\end{array}$ & 0.272 \\
\hline-6 & $\begin{array}{c}0.012 \\
(0.025)\end{array}$ & 0.640 & $\begin{array}{l}-0.005 \\
(0.008)\end{array}$ & 0.559 & $\begin{array}{c}0.004 \\
(0.012)\end{array}$ & 0.726 & $\begin{array}{c}0.010 \\
(0.025)\end{array}$ & 0.676 & $\begin{array}{c}-0.931 \\
(7.879)\end{array}$ & 0.906 & $\begin{array}{c}0.000 \\
(0.019)\end{array}$ & 0.989 & $\begin{array}{c}0.012 \\
(0.016)\end{array}$ & 0.445 & $\begin{array}{c}0.058 \\
(0.056)\end{array}$ & 0.300 \\
\hline-5 & $\begin{array}{c}0.011 \\
(0.025)\end{array}$ & 0.672 & $\begin{array}{l}-0.009 \\
(0.007)\end{array}$ & 0.199 & $\begin{array}{l}-0.007 \\
(0.013)\end{array}$ & 0.584 & $\begin{array}{c}0.011 \\
(0.025)\end{array}$ & 0.668 & $\begin{array}{c}5.656 \\
(7.722)\end{array}$ & 0.464 & $\begin{array}{c}0.011 \\
(0.019)\end{array}$ & 0.553 & $\begin{array}{c}0.014 \\
(0.015)\end{array}$ & 0.323 & $\begin{array}{c}0.050 \\
(0.060)\end{array}$ & 0.406 \\
\hline-4 & $\begin{array}{c}0.021 \\
(0.025)\end{array}$ & 0.392 & $\begin{array}{c}-0.002 \\
(0.008)\end{array}$ & 0.782 & $\begin{array}{c}0.025 \\
(0.013)\end{array}$ & 0.061 & $\begin{array}{c}0.028 \\
(0.025)\end{array}$ & 0.264 & $\begin{array}{l}-2.414 \\
(7.841)\end{array}$ & 0.758 & $\begin{array}{l}-0.001 \\
(0.019)\end{array}$ & 0.972 & $\begin{array}{c}0.002 \\
(0.015)\end{array}$ & 0.913 & $\begin{array}{c}0.010 \\
(0.058)\end{array}$ & 0.856 \\
\hline-3 & $\begin{array}{c}0.023 \\
(0.025)\end{array}$ & 0.342 & $\begin{array}{c}0.006 \\
(0.009)\end{array}$ & 0.459 & $\begin{array}{c}0.001 \\
(0.014)\end{array}$ & 0.928 & $\begin{array}{c}0.022 \\
(0.025)\end{array}$ & 0.375 & $\begin{array}{c}3.392 \\
(7.968)\end{array}$ & 0.670 & $\begin{array}{l}-0.007 \\
(0.020)\end{array}$ & 0.731 & $\begin{array}{c}0.005 \\
(0.016)\end{array}$ & 0.762 & $\begin{array}{c}0.042 \\
(0.055)\end{array}$ & 0.451 \\
\hline-2 & $\begin{array}{c}0.015 \\
(0.024)\end{array}$ & 0.532 & $\begin{array}{c}0.013 \\
(0.009)\end{array}$ & 0.166 & $\begin{array}{c}0.016 \\
(0.015)\end{array}$ & 0.291 & $\begin{array}{c}0.009 \\
(0.024)\end{array}$ & 0.701 & $\begin{array}{l}1.023 \\
(8.000)\end{array}$ & 0.898 & $\begin{array}{c}0.015 \\
(0.020)\end{array}$ & 0.444 & $\begin{array}{c}0.008 \\
(0.016)\end{array}$ & 0.615 & $\begin{array}{c}-0.003 \\
(0.055)\end{array}$ & 0.962 \\
\hline-1 & $\begin{array}{c}-0.002 \\
(0.023)\end{array}$ & 0.925 & $\begin{array}{l}-0.001 \\
(0.013)\end{array}$ & 0.918 & $\begin{array}{c}0.015 \\
(0.017)\end{array}$ & 0.375 & $\begin{array}{c}-0.002 \\
(0.023)\end{array}$ & 0.930 & $\begin{array}{c}-3.774 \\
(8.151)\end{array}$ & 0.643 & $\begin{array}{l}-0.023 \\
(0.021)\end{array}$ & 0.260 & $\begin{array}{c}0.000 \\
(0.016)\end{array}$ & 0.983 & $\begin{array}{c}0.057 \\
(0.052)\end{array}$ & 0.280 \\
\hline 0 & $\begin{array}{c}0.033 \\
(0.021)\end{array}$ & 0.110 & $\begin{array}{c}0.020 \\
(0.020)\end{array}$ & 0.331 & $\begin{array}{c}0.062 \\
(0.022)\end{array}$ & 0.004 & $\begin{array}{c}0.031 \\
(0.020)\end{array}$ & 0.126 & $\begin{array}{c}5.605 \\
(8.345)\end{array}$ & 0.502 & $\begin{array}{l}-0.004 \\
(0.023)\end{array}$ & 0.855 & $\begin{array}{c}0.014 \\
(0.019)\end{array}$ & 0.458 & $\begin{array}{c}0.052 \\
(0.045)\end{array}$ & 0.242 \\
\hline 1 & $\begin{array}{c}0.106 \\
(0.023)\end{array}$ & 0.000 & $\begin{array}{c}0.029 \\
(0.012)\end{array}$ & 0.021 & $\begin{array}{c}0.053 \\
(0.017)\end{array}$ & 0.002 & $\begin{array}{c}0.102 \\
(0.023)\end{array}$ & 0.000 & $\begin{array}{l}21.674 \\
(8.299)\end{array}$ & 0.009 & $\begin{array}{c}0.056 \\
(0.020)\end{array}$ & 0.005 & $\begin{array}{c}0.031 \\
(0.015)\end{array}$ & 0.037 & $\begin{array}{c}0.008 \\
(0.055)\end{array}$ & 0.879 \\
\hline 2 & $\begin{array}{c}0.037 \\
(0.024)\end{array}$ & 0.121 & $\begin{array}{c}0.013 \\
(0.010)\end{array}$ & 0.198 & $\begin{array}{c}0.021 \\
(0.016)\end{array}$ & 0.196 & $\begin{array}{c}0.036 \\
(0.024)\end{array}$ & 0.123 & $\begin{array}{l}14.639 \\
(8.254)\end{array}$ & 0.076 & $\begin{array}{c}0.027 \\
(0.020)\end{array}$ & 0.176 & $\begin{array}{c}0.018 \\
(0.016)\end{array}$ & 0.247 & $\begin{array}{c}0.019 \\
(0.055)\end{array}$ & 0.724 \\
\hline 3 & $\begin{array}{c}0.009 \\
(0.024)\end{array}$ & 0.697 & $\begin{array}{l}-0.005 \\
(0.010)\end{array}$ & 0.655 & $\begin{array}{c}0.027 \\
(0.016)\end{array}$ & 0.084 & $\begin{array}{c}0.016 \\
(0.024)\end{array}$ & 0.510 & $\begin{array}{l}10.884 \\
(8.304)\end{array}$ & 0.190 & $\begin{array}{c}-0.021 \\
(0.020)\end{array}$ & 0.293 & $\begin{array}{c}0.008 \\
(0.015)\end{array}$ & 0.616 & $\begin{array}{c}0.096 \\
(0.055)\end{array}$ & 0.080 \\
\hline 4 & $\begin{array}{c}0.006 \\
(0.024)\end{array}$ & 0.812 & $\begin{array}{c}0.006 \\
(0.009)\end{array}$ & 0.491 & $\begin{array}{c}0.019 \\
(0.015)\end{array}$ & 0.217 & $\begin{array}{c}0.011 \\
(0.024)\end{array}$ & 0.640 & $\begin{array}{l}12.518 \\
(8.047)\end{array}$ & 0.120 & $\begin{array}{l}-0.015 \\
(0.020)\end{array}$ & 0.466 & $\begin{array}{c}0.011 \\
(0.016)\end{array}$ & 0.473 & $\begin{array}{c}0.091 \\
(0.054)\end{array}$ & 0.089 \\
\hline 5 & $\begin{array}{c}-0.004 \\
(0.024)\end{array}$ & 0.858 & $\begin{array}{c}0.001 \\
(0.008)\end{array}$ & 0.867 & $\begin{array}{c}0.020 \\
(0.015)\end{array}$ & 0.192 & $\begin{array}{l}-0.002 \\
(0.024)\end{array}$ & 0.934 & $\begin{array}{c}9.175 \\
(8.108)\end{array}$ & 0.258 & $\begin{array}{l}-0.006 \\
(0.020)\end{array}$ & 0.756 & $\begin{array}{c}0.004 \\
(0.016)\end{array}$ & 0.818 & $\begin{array}{c}0.035 \\
(0.054)\end{array}$ & 0.522 \\
\hline 6 & $\begin{array}{c}0.043 \\
(0.025)\end{array}$ & 0.082 & $\begin{array}{c}0.010 \\
(0.009)\end{array}$ & 0.225 & $\begin{array}{c}0.031 \\
(0.014)\end{array}$ & 0.033 & $\begin{array}{c}0.050 \\
(0.024)\end{array}$ & 0.042 & $\begin{array}{l}18.373 \\
(8.013)\end{array}$ & 0.022 & $\begin{array}{c}0.040 \\
(0.020)\end{array}$ & 0.043 & $\begin{array}{c}0.026 \\
(0.015)\end{array}$ & 0.076 & $\begin{array}{c}0.028 \\
(0.056)\end{array}$ & 0.614 \\
\hline 7 & $\begin{array}{l}-0.018 \\
(0.025)\end{array}$ & 0.475 & $\begin{array}{c}0.012 \\
(0.009)\end{array}$ & 0.182 & $\begin{array}{c}0.019 \\
(0.015)\end{array}$ & 0.205 & $\begin{array}{l}-0.010 \\
(0.024)\end{array}$ & 0.682 & $\begin{array}{l}12.968 \\
(7.883)\end{array}$ & 0.100 & $\begin{array}{c}0.012 \\
(0.020)\end{array}$ & 0.546 & $\begin{array}{c}0.014 \\
(0.016)\end{array}$ & 0.385 & $\begin{array}{c}0.032 \\
(0.054)\end{array}$ & 0.557 \\
\hline 8 & $\begin{array}{c}0.031 \\
(0.025)\end{array}$ & 0.211 & $\begin{array}{c}0.001 \\
(0.007)\end{array}$ & 0.918 & $\begin{array}{c}0.010 \\
(0.014)\end{array}$ & 0.461 & $\begin{array}{c}0.036 \\
(0.025)\end{array}$ & 0.144 & $\begin{array}{c}4.797 \\
(7.348)\end{array}$ & 0.514 & $\begin{array}{c}-0.014 \\
(0.019)\end{array}$ & 0.459 & $\begin{array}{l}-0.001 \\
(0.015)\end{array}$ & 0.927 & $\begin{array}{c}0.034 \\
(0.058)\end{array}$ & 0.563 \\
\hline
\end{tabular}

Note: Table reports regression discontinuity estimates for each quarter with standard errors in parentheses. Quarter 0 corresponds to event months $0,-1$, and -2 relative to the month of application decision. Ambulatory = Any ambulatory encounter. Inpatient = Any inpatient encounter. ED = Any emergency department encounter. Any Encounter = Any ambulatory, inpatient, or ED encounter. RX = Prescription drug days supplied (winsorized at the 95th percentile). Any Lab = Any lab test record. Unconditional Lab $=$ Any abnormal lab result unconditional on having a lab record. Conditional Lab $=$ Any abnormal lab result conditional on having a lab record. Estimates for each quarter are based on regressions with $\mathrm{N}=18,672$ observations. 
Table A5: IV Estimates for Each Quarter

\begin{tabular}{|c|c|c|c|c|c|c|c|c|c|c|c|c|c|c|c|c|}
\hline \multirow[b]{2}{*}{ Quarter } & \multicolumn{2}{|c|}{ Ambulatory } & \multicolumn{2}{|c|}{ Inpatient } & \multicolumn{2}{|c|}{ ED } & \multicolumn{2}{|c|}{ Any Encounter } & \multicolumn{2}{|c|}{$\mathrm{RX}$} & \multicolumn{2}{|c|}{ Any Lab } & \multicolumn{2}{|c|}{ Unconditional Lab } & \multicolumn{2}{|c|}{ Conditional Lab } \\
\hline & Coef & P Value & Coef & P Value & Coef & P Value & Coef & P Value & Coef & P Value & Coef & P Value & Coef & P Value & Coef & P Value \\
\hline-7 & $\begin{array}{c}0.033 \\
(0.032)\end{array}$ & 0.296 & $\begin{array}{l}-0.006 \\
(0.008)\end{array}$ & 0.454 & $\begin{array}{l}-0.020 \\
(0.016)\end{array}$ & 0.223 & $\begin{array}{c}0.029 \\
(0.032)\end{array}$ & 0.353 & $\begin{array}{c}9.562 \\
(9.862)\end{array}$ & 0.332 & $\begin{array}{c}0.011 \\
(0.024)\end{array}$ & 0.627 & $\begin{array}{c}0.021 \\
(0.019)\end{array}$ & 0.273 & $\begin{array}{c}0.074 \\
(0.067)\end{array}$ & 0.270 \\
\hline-6 & $\begin{array}{c}0.015 \\
(0.032)\end{array}$ & 0.641 & $\begin{array}{l}-0.006 \\
(0.010)\end{array}$ & 0.559 & $\begin{array}{c}0.005 \\
(0.015)\end{array}$ & 0.726 & $\begin{array}{c}0.013 \\
(0.031)\end{array}$ & 0.676 & $\begin{array}{c}-1.181 \\
(10.001)\end{array}$ & 0.906 & $\begin{array}{c}0.000 \\
(0.025)\end{array}$ & 0.989 & $\begin{array}{c}0.015 \\
(0.020)\end{array}$ & 0.445 & $\begin{array}{c}0.070 \\
(0.067)\end{array}$ & 0.298 \\
\hline-5 & $\begin{array}{c}0.013 \\
(0.031)\end{array}$ & 0.672 & $\begin{array}{l}-0.012 \\
(0.009)\end{array}$ & 0.199 & $\begin{array}{l}-0.009 \\
(0.017)\end{array}$ & 0.584 & $\begin{array}{c}0.013 \\
(0.031)\end{array}$ & 0.668 & $\begin{array}{l}7.181 \\
(9.815)\end{array}$ & 0.464 & $\begin{array}{c}0.014 \\
(0.024)\end{array}$ & 0.553 & $\begin{array}{c}0.018 \\
(0.018)\end{array}$ & 0.323 & $\begin{array}{c}0.059 \\
(0.070)\end{array}$ & 0.403 \\
\hline-4 & $\begin{array}{c}0.027 \\
(0.031)\end{array}$ & 0.392 & $\begin{array}{l}-0.003 \\
(0.010)\end{array}$ & 0.782 & $\begin{array}{c}0.032 \\
(0.017)\end{array}$ & 0.061 & $\begin{array}{c}0.035 \\
(0.031)\end{array}$ & 0.265 & $\begin{array}{l}-3.065 \\
(9.950)\end{array}$ & 0.758 & $\begin{array}{l}-0.001 \\
(0.024)\end{array}$ & 0.972 & $\begin{array}{c}0.002 \\
(0.019)\end{array}$ & 0.913 & $\begin{array}{c}0.013 \\
(0.070)\end{array}$ & 0.856 \\
\hline-3 & $\begin{array}{c}0.030 \\
(0.031)\end{array}$ & 0.343 & $\begin{array}{c}0.008 \\
(0.011)\end{array}$ & 0.459 & $\begin{array}{c}0.002 \\
(0.018)\end{array}$ & 0.928 & $\begin{array}{c}0.028 \\
(0.031)\end{array}$ & 0.375 & $\begin{array}{c}4.307 \\
(10.121)\end{array}$ & 0.670 & $\begin{array}{l}-0.009 \\
(0.025)\end{array}$ & 0.731 & $\begin{array}{c}0.006 \\
(0.020)\end{array}$ & 0.762 & $\begin{array}{c}0.054 \\
(0.072)\end{array}$ & 0.451 \\
\hline-2 & $\begin{array}{c}0.019 \\
(0.031)\end{array}$ & 0.532 & $\begin{array}{c}0.016 \\
(0.012)\end{array}$ & 0.167 & $\begin{array}{c}0.021 \\
(0.020)\end{array}$ & 0.291 & $\begin{array}{c}0.012 \\
(0.030)\end{array}$ & 0.701 & $\begin{array}{c}1.299 \\
(10.157)\end{array}$ & 0.898 & $\begin{array}{c}0.019 \\
(0.025)\end{array}$ & 0.444 & $\begin{array}{c}0.010 \\
(0.020)\end{array}$ & 0.615 & $\begin{array}{l}-0.003 \\
(0.065)\end{array}$ & 0.962 \\
\hline-1 & $\begin{array}{l}-0.003 \\
(0.030)\end{array}$ & 0.925 & $\begin{array}{l}-0.002 \\
(0.016)\end{array}$ & 0.918 & $\begin{array}{c}0.019 \\
(0.021)\end{array}$ & 0.374 & $\begin{array}{l}-0.003 \\
(0.029)\end{array}$ & 0.930 & $\begin{array}{c}-4.791 \\
(10.343)\end{array}$ & 0.643 & $\begin{array}{l}-0.030 \\
(0.026)\end{array}$ & 0.260 & $\begin{array}{c}0.000 \\
(0.020)\end{array}$ & 0.983 & $\begin{array}{c}0.074 \\
(0.068)\end{array}$ & 0.280 \\
\hline 0 & $\begin{array}{c}0.042 \\
(0.026)\end{array}$ & 0.110 & $\begin{array}{c}0.025 \\
(0.026)\end{array}$ & 0.331 & $\begin{array}{c}0.079 \\
(0.027)\end{array}$ & 0.004 & $\begin{array}{c}0.039 \\
(0.025)\end{array}$ & 0.126 & $\begin{array}{c}7.116 \\
(10.600)\end{array}$ & 0.502 & $\begin{array}{l}-0.005 \\
(0.029)\end{array}$ & 0.855 & $\begin{array}{c}0.017 \\
(0.023)\end{array}$ & 0.458 & $\begin{array}{c}0.065 \\
(0.055)\end{array}$ & 0.241 \\
\hline 1 & $\begin{array}{c}0.134 \\
(0.029)\end{array}$ & 0.000 & $\begin{array}{c}0.036 \\
(0.016)\end{array}$ & 0.021 & $\begin{array}{c}0.067 \\
(0.022)\end{array}$ & 0.002 & $\begin{array}{c}0.130 \\
(0.029)\end{array}$ & 0.000 & $\begin{array}{c}27.519 \\
(10.589)\end{array}$ & 0.009 & $\begin{array}{c}0.071 \\
(0.025)\end{array}$ & 0.005 & $\begin{array}{c}0.040 \\
(0.019)\end{array}$ & 0.037 & $\begin{array}{c}0.010 \\
(0.067)\end{array}$ & 0.879 \\
\hline 2 & $\begin{array}{c}0.047 \\
(0.030)\end{array}$ & 0.121 & $\begin{array}{c}0.017 \\
(0.013)\end{array}$ & 0.199 & $\begin{array}{c}0.027 \\
(0.020)\end{array}$ & 0.196 & $\begin{array}{c}0.046 \\
(0.030)\end{array}$ & 0.123 & $\begin{array}{c}18.587 \\
(10.503)\end{array}$ & 0.077 & $\begin{array}{c}0.034 \\
(0.025)\end{array}$ & 0.176 & $\begin{array}{c}0.023 \\
(0.020)\end{array}$ & 0.247 & $\begin{array}{c}0.023 \\
(0.065)\end{array}$ & 0.723 \\
\hline 3 & $\begin{array}{c}0.012 \\
(0.031)\end{array}$ & 0.697 & $\begin{array}{l}-0.006 \\
(0.013)\end{array}$ & 0.655 & $\begin{array}{c}0.034 \\
(0.020)\end{array}$ & 0.085 & $\begin{array}{c}0.020 \\
(0.030)\end{array}$ & 0.510 & $\begin{array}{c}13.819 \\
(10.561)\end{array}$ & 0.191 & $\begin{array}{l}-0.027 \\
(0.025)\end{array}$ & 0.294 & $\begin{array}{c}0.010 \\
(0.020)\end{array}$ & 0.616 & $\begin{array}{c}0.130 \\
(0.074)\end{array}$ & 0.081 \\
\hline 4 & $\begin{array}{c}0.007 \\
(0.031)\end{array}$ & 0.812 & $\begin{array}{c}0.008 \\
(0.011)\end{array}$ & 0.491 & $\begin{array}{c}0.024 \\
(0.019)\end{array}$ & 0.217 & $\begin{array}{c}0.014 \\
(0.031)\end{array}$ & 0.640 & $\begin{array}{c}15.894 \\
(10.225)\end{array}$ & 0.120 & $\begin{array}{l}-0.019 \\
(0.026)\end{array}$ & 0.466 & $\begin{array}{c}0.014 \\
(0.020)\end{array}$ & 0.473 & $\begin{array}{c}0.115 \\
(0.068)\end{array}$ & 0.089 \\
\hline 5 & $\begin{array}{l}-0.006 \\
(0.031)\end{array}$ & 0.858 & $\begin{array}{c}0.002 \\
(0.011)\end{array}$ & 0.867 & $\begin{array}{c}0.025 \\
(0.019)\end{array}$ & 0.192 & $\begin{array}{l}-0.003 \\
(0.031)\end{array}$ & 0.934 & $\begin{array}{c}11.649 \\
(10.304)\end{array}$ & 0.258 & $\begin{array}{l}-0.008 \\
(0.025)\end{array}$ & 0.756 & $\begin{array}{c}0.005 \\
(0.020)\end{array}$ & 0.818 & $\begin{array}{c}0.043 \\
(0.067)\end{array}$ & 0.521 \\
\hline 6 & $\begin{array}{c}0.054 \\
(0.031)\end{array}$ & 0.083 & $\begin{array}{c}0.013 \\
(0.011)\end{array}$ & 0.225 & $\begin{array}{c}0.039 \\
(0.018)\end{array}$ & 0.033 & $\begin{array}{c}0.063 \\
(0.031)\end{array}$ & 0.042 & $\begin{array}{c}23.328 \\
(10.212)\end{array}$ & 0.022 & $\begin{array}{c}0.051 \\
(0.025)\end{array}$ & 0.043 & $\begin{array}{c}0.033 \\
(0.019)\end{array}$ & 0.076 & $\begin{array}{c}0.035 \\
(0.070)\end{array}$ & 0.614 \\
\hline 7 & $\begin{array}{l}-0.022 \\
(0.031)\end{array}$ & 0.475 & $\begin{array}{c}0.015 \\
(0.011)\end{array}$ & 0.182 & $\begin{array}{c}0.024 \\
(0.019)\end{array}$ & 0.205 & $\begin{array}{l}-0.013 \\
(0.031)\end{array}$ & 0.682 & $\begin{array}{c}16.465 \\
(10.025)\end{array}$ & 0.101 & $\begin{array}{c}0.016 \\
(0.026)\end{array}$ & 0.546 & $\begin{array}{c}0.018 \\
(0.020)\end{array}$ & 0.385 & $\begin{array}{c}0.040 \\
(0.068)\end{array}$ & 0.556 \\
\hline 8 & $\begin{array}{c}0.039 \\
(0.031)\end{array}$ & 0.211 & $\begin{array}{c}0.001 \\
(0.009)\end{array}$ & 0.918 & $\begin{array}{c}0.013 \\
(0.018)\end{array}$ & 0.461 & $\begin{array}{c}0.046 \\
(0.031)\end{array}$ & 0.144 & $\begin{array}{c}6.090 \\
(9.331)\end{array}$ & 0.514 & $\begin{array}{l}-0.018 \\
(0.024)\end{array}$ & 0.459 & $\begin{array}{l}-0.002 \\
(0.019)\end{array}$ & 0.927 & $\begin{array}{c}0.044 \\
(0.076)\end{array}$ & 0.561 \\
\hline
\end{tabular}

Note: Table reports IV estimates for each quarter with standard errors in parentheses. Quarter 0 corresponds to event months 0 , -1 , and -2 relative to the month of application decision. Ambulatory = Any ambulatory encounter. Inpatient = Any inpatient encounter. ED = Any emergency department encounter. Any Encounter $=$ Any encounter including ambulatory, inpatient, or ED. RX = Prescription drug days supplied (winsorized at the 95th percentile). Any Lab $=$ Any lab test record. Unconditional Lab = Any abnormal lab results unconditional on having a lab record. Conditional Lab = Any abnormal lab results conditional on having a lab record. Estimates for each quarter are based on regressions with $\mathrm{N}=18,672$ observations. 
Table A6: RD Estimates, Alternative Specifications

\begin{tabular}{|c|c|c|c|c|c|c|c|}
\hline & \multirow[b]{2}{*}{ Control Mean } & \multicolumn{3}{|c|}{ Reduced Form } & \multicolumn{3}{|c|}{ Instrumental Variables } \\
\hline & & Coef (SE) & $95 \% \mathrm{CI}$ & P-value & Coef (SE) & $95 \% \mathrm{CI}$ & P-value \\
\hline \multicolumn{8}{|l|}{ Panel A. Separate Polynomials on Either Side of Cutoff } \\
\hline Any Ambulatory Encounter & 0.670 & $\begin{array}{r}0.115 \\
(0.032)\end{array}$ & {$[0.052,0.178]$} & 0.000 & $\begin{array}{r}0.146 \\
(0.041)\end{array}$ & {$[0.066,0.226]$} & 0.000 \\
\hline Any Inpatient Encounter & 0.062 & $\begin{array}{r}0.033 \\
(0.017)\end{array}$ & {$[-0.000,0.067]$} & 0.052 & $\begin{array}{r}0.042 \\
(0.022)\end{array}$ & {$[-0.000,0.085]$} & 0.052 \\
\hline Any Emergency Department Encounter & 0.127 & $\begin{array}{r}0.065 \\
(0.023)\end{array}$ & {$[0.020,0.110]$} & 0.005 & $\begin{array}{r}0.083 \\
(0.030)\end{array}$ & {$[0.025,0.141]$} & 0.005 \\
\hline Any Encounter (Ambulatory, Inpatient, or ED) & 0.684 & $\begin{array}{r}0.116 \\
(0.032)\end{array}$ & {$[0.054,0.179]$} & 0.000 & $\begin{array}{r}0.148 \\
(0.040)\end{array}$ & {$[0.069,0.227]$} & 0.000 \\
\hline Prescription Drug Days Supplied ${ }^{\dagger}$ & 131.203 & $\begin{array}{r}35.255 \\
(11.142)\end{array}$ & {$[13.416,57.095]$} & 0.002 & $\begin{array}{r}44.807 \\
(14.329)\end{array}$ & {$[16.723,72.891]$} & 0.002 \\
\hline Any Lab Test & 0.194 & $\begin{array}{r}0.064 \\
(0.027)\end{array}$ & {$[0.011,0.117]$} & 0.018 & $\begin{array}{r}0.081 \\
(0.034)\end{array}$ & [ 0.014, 0.149] & 0.018 \\
\hline Any Abnormal Test Result (Unconditional) & 0.100 & $\begin{array}{r}0.046 \\
(0.020)\end{array}$ & {$[0.006,0.086]$} & 0.023 & $\begin{array}{r}0.058 \\
(0.026)\end{array}$ & {$[0.008,0.109]$} & 0.023 \\
\hline Any Abnormal Test Result (Conditional on Test) & 0.515 & $\begin{array}{r}0.078 \\
(0.079)\end{array}$ & {$[-0.076,0.232]$} & 0.321 & $\begin{array}{r}0.096 \\
(0.097)\end{array}$ & {$[-0.095,0.287]$} & 0.323 \\
\hline \multicolumn{8}{|l|}{ Panel B. Locally Linear Polynomials on Either Side of Cutoff } \\
\hline Any Ambulatory Encounter & 0.670 & $\begin{array}{r}0.091 \\
(0.051)\end{array}$ & {$[-0.010,0.191]$} & 0.077 & $\begin{array}{r}0.118 \\
(0.059)\end{array}$ & {$[0.003,0.233]$} & 0.044 \\
\hline Any Inpatient Encounter & 0.062 & $\begin{array}{r}0.023 \\
(0.029)\end{array}$ & {$[-0.034,0.080]$} & 0.427 & $\begin{array}{r}0.031 \\
(0.037)\end{array}$ & {$[-0.041,0.102]$} & 0.403 \\
\hline Any Emergency Department Encounter & 0.127 & $\begin{array}{r}0.057 \\
(0.038)\end{array}$ & {$[-0.017,0.130]$} & 0.132 & $\begin{array}{r}0.069 \\
(0.049)\end{array}$ & {$[-0.027,0.165]$} & 0.158 \\
\hline Any Encounter (Ambulatory, Inpatient, or ED) & 0.684 & $\begin{array}{r}0.103 \\
(0.048)\end{array}$ & {$[0.009,0.197]$} & 0.031 & $\begin{array}{r}0.131 \\
(0.057)\end{array}$ & {$[0.019,0.243]$} & 0.022 \\
\hline Prescription Drug Days Supplied ${ }^{+}$ & 131.203 & $\begin{array}{r}1.442 \\
(19.071)\end{array}$ & {$[-35.936,38.821]$} & 0.940 & $\begin{array}{r}18.397 \\
(22.064)\end{array}$ & {$[-24.848,61.642]$} & 0.404 \\
\hline Any Lab Test & 0.194 & $\begin{array}{r}0.079 \\
(0.044)\end{array}$ & {$[-0.007,0.166]$} & 0.072 & $\begin{array}{r}0.103 \\
(0.057)\end{array}$ & {$[-0.009,0.215]$} & 0.071 \\
\hline Any Abnormal Test Result (Unconditional) & 0.100 & $\begin{array}{r}0.019 \\
(0.031)\end{array}$ & {$[-0.041,0.079]$} & 0.537 & $\begin{array}{r}0.044 \\
(0.035)\end{array}$ & {$[-0.024,0.112]$} & 0.202 \\
\hline Any Abnormal Test Result (Conditional on Test) & 0.515 & $\begin{array}{r}-0.086 \\
(0.122)\end{array}$ & {$[-0.326,0.154]$} & 0.483 & $\begin{array}{r}-0.127 \\
(0.160)\end{array}$ & {$[-0.442,0.187]$} & 0.427 \\
\hline \multicolumn{8}{|l|}{ Panel C. Donut RD } \\
\hline Any Ambulatory Encounter & 0.678 & $\begin{array}{r}0.105 \\
(0.026)\end{array}$ & {$[0.054,0.157]$} & 0.000 & $\begin{array}{r}0.133 \\
(0.033)\end{array}$ & {$[0.067,0.199]$} & 0.000 \\
\hline Any Inpatient Encounter & 0.058 & $\begin{array}{r}0.036 \\
(0.014)\end{array}$ & {$[0.009,0.063]$} & 0.008 & $\begin{array}{r}0.046 \\
(0.017)\end{array}$ & {$[0.012,0.080]$} & 0.008 \\
\hline Any Emergency Department Encounter & 0.128 & $\begin{array}{r}0.054 \\
(0.020)\end{array}$ & {$[0.015,0.092]$} & 0.006 & $\begin{array}{r}0.068 \\
(0.025)\end{array}$ & {$[0.019,0.117]$} & 0.007 \\
\hline Any Encounter (Ambulatory, Inpatient, or ED) & 0.693 & $\begin{array}{r}0.097 \\
(0.026)\end{array}$ & {$[0.046,0.148]$} & 0.000 & $\begin{array}{r}0.123 \\
(0.033)\end{array}$ & {$[0.058,0.188]$} & 0.000 \\
\hline Prescription Drug Days Supplied ${ }^{+}$ & 136.203 & $\begin{array}{r}21.482 \\
(9.795)\end{array}$ & {$[2.283,40.682]$} & 0.028 & $\begin{array}{r}27.123 \\
(12.417)\end{array}$ & {$[2.786,51.460]$} & 0.029 \\
\hline Any Lab Test & 0.200 & $\begin{array}{r}0.054 \\
(0.023)\end{array}$ & {$[0.008,0.100]$} & 0.022 & $\begin{array}{r}0.068 \\
(0.030)\end{array}$ & {$[0.010,0.126]$} & 0.022 \\
\hline Any Abnormal Test Result (Unconditional) & 0.106 & $\begin{array}{r}0.029 \\
(0.018)\end{array}$ & {$[-0.006,0.064]$} & 0.102 & $\begin{array}{r}0.037 \\
(0.023)\end{array}$ & {$[-0.007,0.081]$} & 0.102 \\
\hline Any Abnormal Test Result (Conditional on Test) & 0.531 & $\begin{array}{r}0.003 \\
(0.062)\end{array}$ & {$[-0.120,0.125]$} & 0.965 & $\begin{array}{r}0.003 \\
(0.073)\end{array}$ & {$[-0.140,0.146]$} & 0.965 \\
\hline \multicolumn{8}{|l|}{ Panel D. Count Outcomes } \\
\hline Number of Ambulatory Encounters ${ }^{\dagger}$ & 3.813 & $\begin{array}{r}0.516 \\
(0.244)\end{array}$ & {$[0.038,0.994]$} & 0.034 & $\begin{array}{r}0.655 \\
(0.310)\end{array}$ & {$[0.047,1.264]$} & 0.035 \\
\hline Number of Inpatient Encounters ${ }^{+}$ & 0.062 & $\begin{array}{r}0.029 \\
(0.012)\end{array}$ & {$[0.004,0.053]$} & 0.021 & $\begin{array}{r}0.036 \\
(0.016)\end{array}$ & {$[0.006,0.067]$} & 0.021 \\
\hline Number of Emergency Department Encounters ${ }^{+}$ & 0.166 & $\begin{array}{r}0.073 \\
(0.024)\end{array}$ & {$[0.027,0.120]$} & 0.002 & $\begin{array}{r}0.093 \\
(0.030)\end{array}$ & {$[0.034,0.152]$} & 0.002 \\
\hline Total Number of Encounters (Ambulatory, Inpatient, ED) ${ }^{+}$ & 4.129 & $\begin{array}{r}0.636 \\
(0.267)\end{array}$ & {$[0.113,1.159]$} & 0.017 & $\begin{array}{r}0.807 \\
(0.340)\end{array}$ & {$[0.142,1.473]$} & 0.017 \\
\hline
\end{tabular}

Note: Table reports alternative specifications of the regression discontinuity estimates for quarter 1 with standard errors in parentheses. Panel A reports estimates that control for separate second-order polynomials in income on either side of the threshold. Panel B shows estimates that control for local linear polynomials using the optimal bandwidth proposed by Calonico et. al (2014). Panel C reports estimates that control for a global second-order polynomial, as we do in our baseline specification, but excludes applicants with incomes $\pm 10 \%$ FPL from the cutoff ( $340-360 \%$ FPL). Panel D shows estimates that control for a global second-order polynomial, as we do in our baseline specification, but with count outcomes as the dependent variables.

${ }^{\dagger}$ Winsorized at the 95th percentile. Control mean is the mean for applicants with incomes between $350 \%$ and $450 \%$ of FPL. N $=18,672$ observations. 
Table A7: Proportional Effect Comparison with Oregon Health Insurance Experiment

\begin{tabular}{|c|c|c|c|c|c|c|c|}
\hline \multicolumn{4}{|c|}{ Kaiser Medical Financial Assistance Program } & \multicolumn{4}{|c|}{ Oregon Health Insurance Experiment } \\
\hline Outcome & $\begin{array}{l}\text { Q1 RD } \\
\text { estimate } \\
(\mathrm{IV})\end{array}$ & $\begin{array}{l}\text { Q1 mean value } \\
\text { in control group } \\
(350-450 \% \text { FPL })\end{array}$ & $\begin{array}{l}\text { Proportional } \\
\text { effect }\end{array}$ & Outcome & $\begin{array}{l}\text { Effect } \\
\text { (LATE) }\end{array}$ & $\begin{array}{l}\text { Mean value } \\
\text { in control } \\
\text { group }\end{array}$ & $\begin{array}{l}\text { Proportional } \\
\text { effect }\end{array}$ \\
\hline $\begin{array}{l}\text { Any Ambulatory } \\
\text { Encounter }\end{array}$ & $13.4 \%$ & $67.0 \%$ & $20.0 \%$ & Any Outpatient Visits + & $21.20 \%$ & $57.4 \%$ & $36.9 \%$ \\
\hline $\begin{array}{l}\text { Any Inpatient En- } \\
\text { counter }\end{array}$ & $3.6 \%$ & $6.2 \%$ & $58.1 \%$ & $\begin{array}{l}\text { Any Inpatient Hospital } \\
\text { Admissionst }\end{array}$ & $0.77 \%$ & $7.2 \%$ & $10.7 \%$ \\
\hline $\begin{array}{l}\text { Any Emergency De- } \\
\text { partment Encouter }\end{array}$ & $6.7 \%$ & $12.7 \%$ & $52.8 \%$ & $\begin{array}{l}\text { Any Emergency De- } \\
\text { partment Visits } \ddagger\end{array}$ & $7.0 \%$ & $34.5 \%$ & $20.3 \%$ \\
\hline $\begin{array}{l}\text { Prescription Drug } \\
\text { Days Supplied }\end{array}$ & 27.5 & 131.2 & $21.0 \%$ & $\begin{array}{l}\text { Number of Current } \\
\text { Prescription Drugst }\end{array}$ & 2.3 & 0.3 & $15.0 \%$ \\
\hline
\end{tabular}

tSource: Table V, Finkelstein et al. (2012). Outcome measures are from survey responses (with a 6-month look-back period for outpatient visits and inpatient admissions), where the average survey response occurs about 15 months after notification date.

‡Source: Table 2, Taubman et al. (2014). Outcome measure is from administrative data over an 18-month study period. 


\section{Figure A1: RD Estimates for Quarter -1}
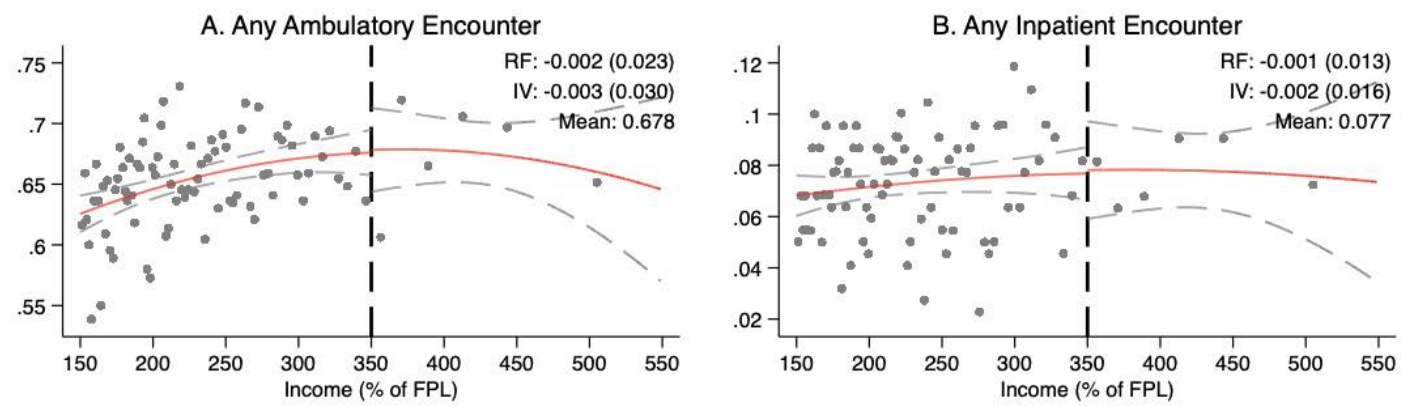

\section{Any Emergency Department Encounter}
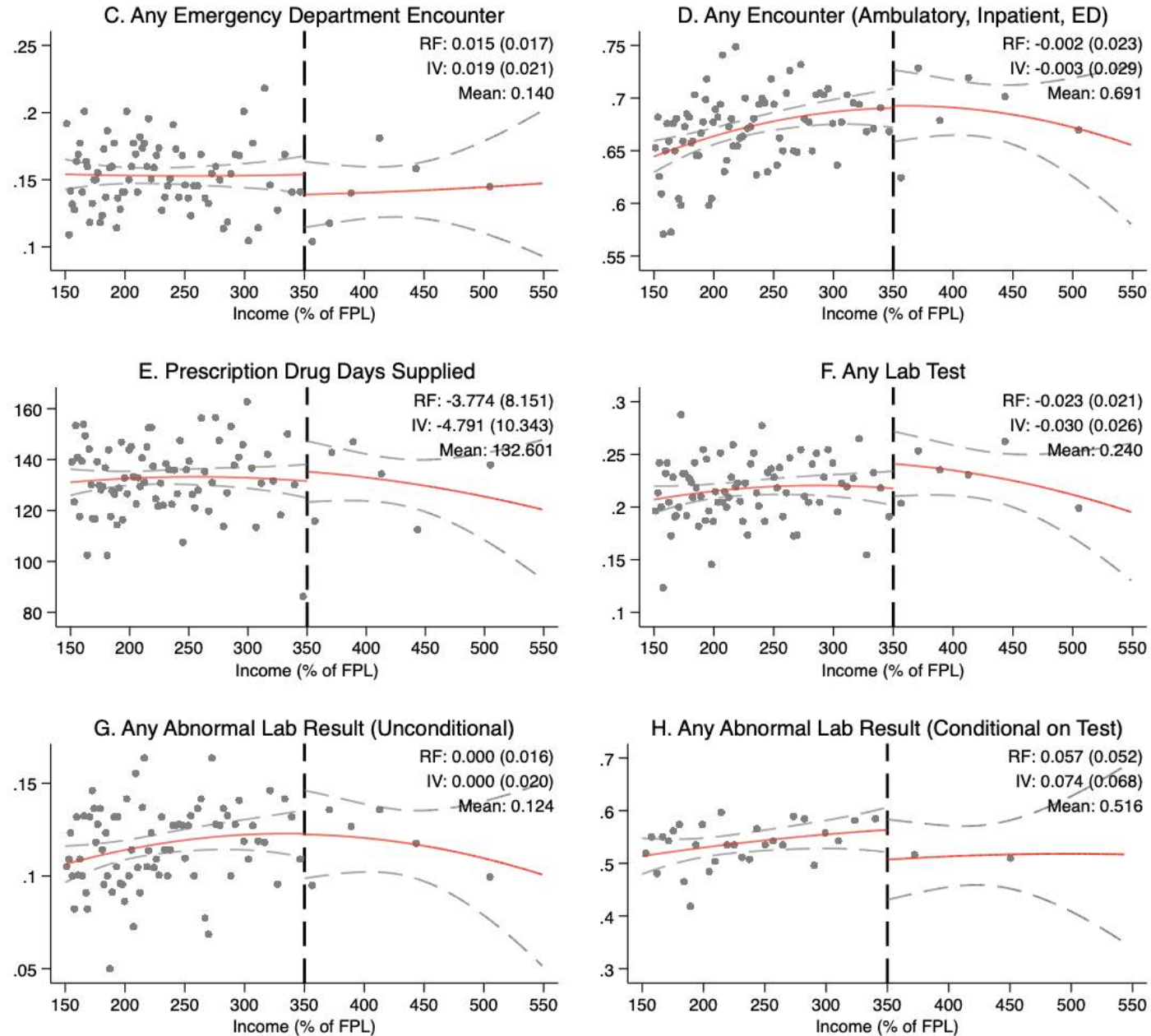

Note: Figure shows regression discontinuity plots of the impact of financial assistance in quarter -1 , which corresponds to event months $-3,-4$, and -5 relative to the month of application decision. Dots show mean of the outcome for 85 equal-frequency bins (220 applicants per bin, except for Panel $G$ where there are 130 applicants per bin). Solid lines show fitted values from a second-order polynomial; dashed lines show $95 \%$ confidence intervals. For each outcome, we also report the RD and IV estimates, their standard errors, and the mean of the outcome for applicants with an income of 350-450\% of FPL (i.e., the "control group" mean). $\mathrm{N}=18,672$ observations. 


\section{Figure A2: RD Estimates for Quarter 0}
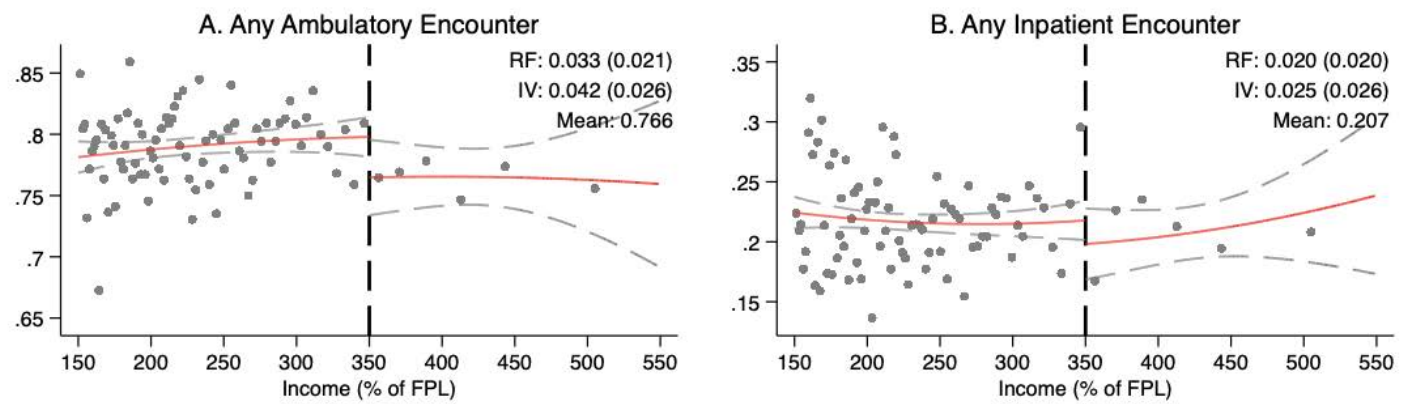

\section{Any Emergency Department Encounter}

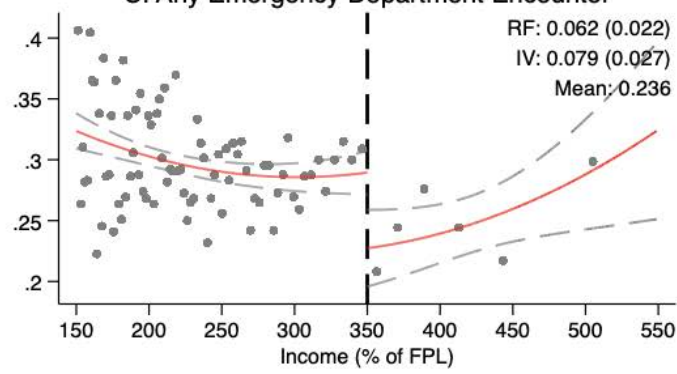

D. Any Encounter (Ambulatory, Inpatient, ED)

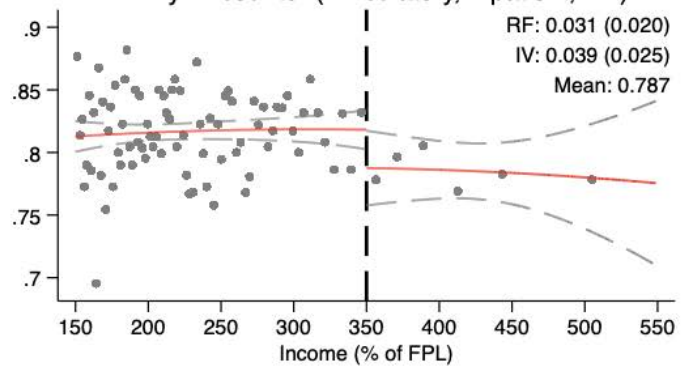

\section{E. Prescription Drug Days Supplied}
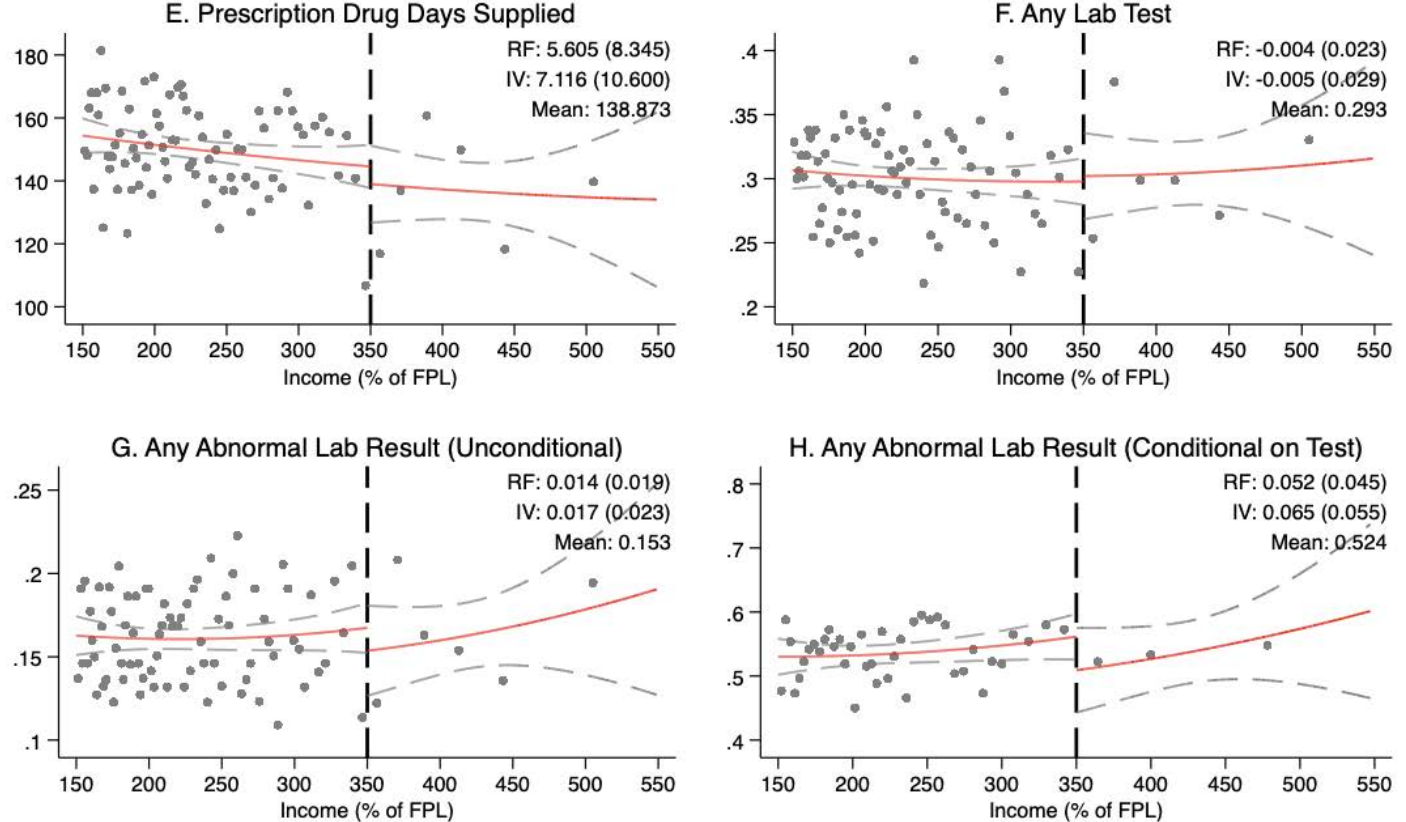

Note: Figure shows regression discontinuity plots of the impact of financial assistance in quarter 0 , which corresponds to event months $0,-1$, and -2 relative to the month of application decision. Dots show mean of the outcome for 85 equal-frequency bins (220 applicants per bin, except for Panel $G$ where there are 130 applicants per bin). Solid lines show fitted values from a second-order polynomial; dashed lines show $95 \%$ confidence intervals. For each outcome, we also report the RD and IV estimates, their standard errors, and the mean of the outcome for applicants with an income of 350-450\% of FPL (i.e., the "control group" mean). $\mathrm{N}=18,672$ observations. 


\section{Figure A3: Distribution of P-values for Placebo Manipulation Tests}
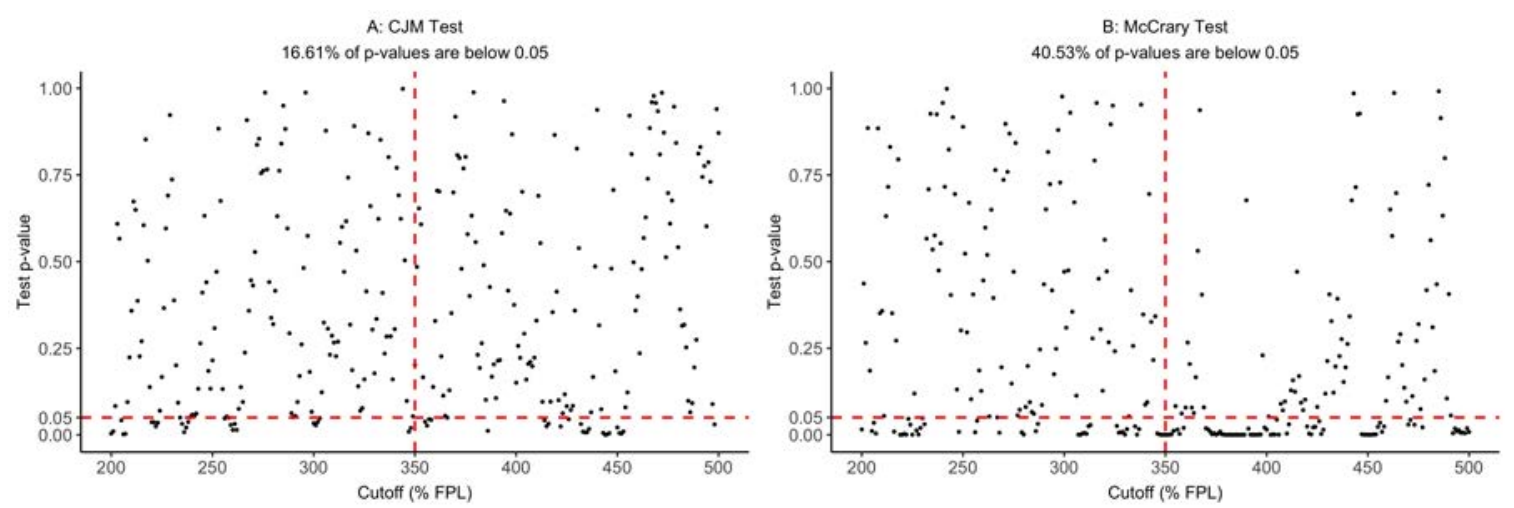

Note: Panels A shows the p-values from placebo CJM tests conducted at $1 \%$ increments for the 301 points between 200\% and 500\% FPL. Panels B shows the p-values from 301 placebo McCrary manipulation tests conducted at the same increments. The vertical dashed lines show the actual 350\% FPL cutoff for the financial assistance program. The horizontal dashed lines show the conventional $0.05 \mathrm{p}$-value threshold for rejecting the null of no manipulation. 